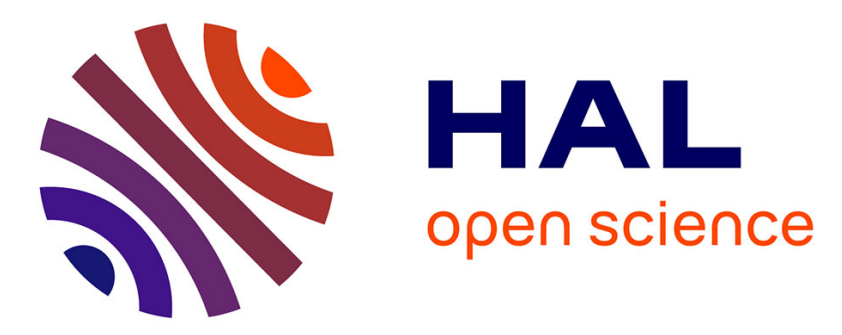

\title{
Source and tectono-metamorphic evolution of mafic and pelitic metasedimentary rocks from the central Quetico metasedimentary belt, Archean Superior Province of Canada.
}

\author{
Franck Valli, Stéphane Guillot, Kéiko Hattori
}

\section{To cite this version:}

Franck Valli, Stéphane Guillot, Kéiko Hattori. Source and tectono-metamorphic evolution of mafic and pelitic metasedimentary rocks from the central Quetico metasedimentary belt, Archean Superior Province of Canada.. Precambrian Research, 2004, 132, pp.155-177. hal-00103140

\author{
HAL Id: hal-00103140 \\ https://hal.science/hal-00103140
}

Submitted on 5 Oct 2006

HAL is a multi-disciplinary open access archive for the deposit and dissemination of scientific research documents, whether they are published or not. The documents may come from teaching and research institutions in France or abroad, or from public or private research centers.
L'archive ouverte pluridisciplinaire $\mathbf{H A L}$, est destinée au dépôt et à la diffusion de documents scientifiques de niveau recherche, publiés ou non, émanant des établissements d'enseignement et de recherche français ou étrangers, des laboratoires publics ou privés. 


\title{
Source and tectono-metamorphic evolution of mafic and pelitic metasedimentary rocks from the central Quetico metasedimentary belt, Archean Superior Province of Canada
}

\author{
Franck Valli $^{{ }^{*}}$, Stephane Guillot ${ }^{\mathrm{b}}$ and Kéiko H. Hattori ${ }^{\mathrm{c}}$ \\ ${ }^{a}$ Laboratoire de Tectonique, IPG-Paris, 4 place jussieu 75252 Paris cedex 05 France \\ ${ }^{b}$ Laboratoire Dynamique de la Lithosphère, CNRS, UCB-Lyon et ENS-Lyon,27 Bd du Novembre, 69622 \\ Villeurbanne cedex France \\ ${ }^{c}$ Department of Earth Sciences, University of Ottawa, Ottawa, Ontario, K1N 6N5 Canada
}

\begin{abstract}
A study of the Jean Lake area of the Quetico metasedimentary belt, Superior Province, Canada, was conducted in order to evaluate the origin, source and evolution of sedimentary rocks, including mafic rocks previously mapped as ultramafics rocks. Bulk chemical compositions of these rocks show a mixing with two end members: quartzo-feldspathic sediments and komatiitic basalts. High $\mathrm{CaO}$ and $\mathrm{MgO}$ contents of the rocks suggest a proximal source of komatiitic basalts, probably from the southern Wabigoon subprovince.

The rocks in the Jean Lake area record a pressure-temperature (P-T) path with three tectonometamorphic stages. The first stage formed staurolite $\left(500-700^{\circ} \mathrm{C}\right)$ under medium P-T (MP-MT) metamorphic conditions shortly after the sedimentation. The second stage yielded the biotitesillimanite-garnet assemblage under the peak condition of $0.6 \pm 0.1 \mathrm{GPa}$ and $700 \pm 70^{\circ} \mathrm{C}$ during transpressional deformation. The third stage, low P- medium $\mathrm{T}\left(0.25 \pm 0.11 \mathrm{GPa}, 540 \pm 80^{\circ} \mathrm{C}\right)$ metamorphism, was associated with regional south-southeast compression and its timing is constrained by a new U-Th- $\mathrm{Pb}$ monazite age of $2667 \pm 20$ Ma. Combining the regional deformation events, we suggest that the sediments in the Jean Lake area were buried up to MPMT conditions during the D1 deformation at 2698-2689 Ma. They attained the peak metamorphic condition during the regional transpressive D2-D3 deformation (2689-2671 Ma), and retrograded to LP-MT condition during the south-southeast compression of the regional D4 at 2671-2667 Ma.

The tectono-metamorphic history of the study area is consistent with the sedimentation in an accretionary prism followed by its docking to the Wabigoon subprovince to the north and Wawa greenstone belt to the south. The P-T-time path of this Archean accretionary prism is similar to that in modern arc accretion systems, except for a higher temperature gradient, $\sim 30^{\circ} \mathrm{C} / \mathrm{km}$, recorded in the Quetico belt compared to $\sim 10^{\circ} \mathrm{C} / \mathrm{km}$ in modern counterparts. The high temperature gradients in the Quetico belt explain the lack of high-pressure metamorphic rocks, such as blueschist, that are common in modern accretionary prisms.
\end{abstract}

Key words: Archean accretionary prism, provenance, geochemistry of clastic sedimentary rocks, cratonization, geothermal gradient, subduction zone, monazite geochronology.

*Corresponding author. Franck Valli, valli@ipgp.jussieu.fr

Tel: 33144272439 Fax: 33144272440 


\section{Introduction}

The Archean Superior Province contains linear arrays of granite-greenstone belts and metasedimentary belts. Successive accretion of volcanic arcs in late Archean time (Card, 1990; Thurston and Chivers, 1990; Fig. 1) is considered as a likely process for the formation of the Archean craton. This is supported by "frozen subduction zones" shown in seismic reflection profiles across the Canadian Shield (Ludden et al., 1993; Calvert et al., 1995; Cook et al., 1999). Metasedimentary belts between greenstone belts are considered to represent accretionary prisms developed during subduction and collision of arcs (Percival, 1989; Card, 1990; Williams, 1990).

The Quetico Subprovince is one such metasedimentary belt in the western Superior Province and is bounded by two volcanic belts: the Wabigoon Subprovince to the north and by the Wawa Subprovince to the south (Figs. 1,2). The Quetico Subprovince consists mostly of turbiditic quartz-rich metasedimentary rocks with minor banded iron formations. In this monotonous sedimentary belt, a lens of "ultramafic rocks", $\sim 2 \mathrm{~km}$ long and $400 \mathrm{~m}$ wide, crops out near Jean Lake, north of Lake Superior (Williams, 1988; 1991; Fralick et al., 1992; Fig. 2). Earlier work suggested that this lens was formed by weathering of ophiolites or serpentinite diapirs (Williams, 1988, 1990; Fralick et al., 1992). Ophiolites and serpentinite diapirs are common in modern convergent margins (Nicolas, 1989; Fryer et al., 1995), but their occurrence of Archean age is in debate (e.g., Hamilton, 1998; DeWit, 1998). Therefore, the "ultramafic" unit in the Quetico belt may provide information relevant to Archean tectonics, and may shed additional light on the evolution of the Quetico metasedimentary belt. In addition, the deformational of the Quetico sedimentary rocks are poorly dated and their metamorphic evolution has not been studied. Such a study will contribute to better understanding of the origin of the belt. Consequently, a study of the "ultramafic" rocks was conducted with four objectives: (i) to characterize the "ultramafic" rocks, (ii) to evaluate their origin and source, (iii) to examine the structural and metamorphic evolution of the "ultramafic" and surrounding rocks, and (iv) to compare the Quetico belt with modern accretionary prisms.

\section{Geological setting}

The Quetico Subprovince is a linear belt of dominantly quartz-rich, turbiditic metagraywackes (Ojakangas, 1985) that has a relatively consistent width of about $70 \mathrm{~km}$ and extends approximately $1200 \mathrm{~km}$ from longitude $70^{\circ} \mathrm{W}$ up to $96^{\circ} \mathrm{W}$ (Williams, 1991). The timing of sedimentation is constrained, by the youngest $\mathrm{U}-\mathrm{Pb}$ age of zircon in the sedimentary rocks and the oldest age of intrusions. There is a difference in the youngest ages of zircon between the north and south: $2698 \mathrm{Ma}$ in the northern part and $2690 \mathrm{Ma}$ in the southern part of the Quetico belt. The oldest U-Pb zircon intrusion age is $2696 \mathrm{Ma}$ in the northern Quetico belt (Zaleski et al., 1999) and $\sim 2670$ Ma for granitic intrusions in the south Quetico belt (Percival, 1989; Williams, 1991). The data indicate that the sedimentary rocks in the southern part of the belt deposited significantly later than the northern part-

Igneous rocks are volumetrically minor in the Quetico belt. They include rare felsic volcanic rocks (Williams, 1991), tonalitic-granodioritic intrusions dated at $2696 \mathrm{Ma}$ (Davis et al., 1990; Zaleski et al., 1999), a suite of carbonate-bearing alkaline complexes of $2680 \pm 1$ Ma (Hattori and Percival, 1999; Lassen et al., 2000), and large aluminous granites dated between $\sim 2670$ and 2650 Ma (Percival, 1989; Williams, 1991).

The Wabigoon Subprovince to the north consists of igneous rocks formed during several magmatic pulses: 3005-2990 Ma mafic-felsic volcanic and tonalite complexes, 2750-2700 Ma mafic-felsic volcanic rocks and $\sim 2690 \mathrm{Ma}$ monzodiorite-diorite and mafic-ultramafic suites 
(Sutcliffe et al., 1989; Blackburn et al., 1991). The Wawa Subprovince to the south is composed of 2750-2690 Ma old ultramafic, mafic and felsic volcanic rocks and related intrusions (Williams, 1990).

\section{Occurrence of mafic rocks in the Jean Lake area}

\subsection{Distribution and lithology}

The "ultramafic" lens is well exposed on the shores and on small islands in the Jean Lake (Fig. 2). Rocks contain millimetre-size clasts of quartz aggregates and exhibit sedimentary textures, including climbing ripples, flame structure, loading and stratification (Figs. 3a, 3b and $3 \mathrm{c})$. These observations suggest a sedimentary origin of these rocks. Bedding and foliation strike east, dip mainly south (between $85^{\circ}$ north and $50^{\circ}$ south) and the "ultramafic" lens is surrounded by quartzo-feldspathic metasedimentary rocks similar to those in the remainder of the Quetico belt.

The quartzo-feldspathic rocks consist of two lithological units, a volumetrically dominant semi-aluminous unit (45-25 vol \% of Qtz, 50-30 vol \% of feldspar, 35-10 vol \% of Bt, <35 vol \% of Chl, $<10 \mathrm{vol} \%$ of Ms and $<10 \mathrm{vol} \%$ of Grt, abbreviations are from Kretz, 1983) and a minor aluminous unit (40-25 vol \% of Qtz, 40-30 vol \% of feldspar, 30-20 vol \% of Bt, 30-5 vol \% of St, $<10$ vol \% of Chl, $<5$ vol \% of Ms and $<5 \%$ of Grt). The "ultramafic lens" contains three units; biotite-amphibole-rich unit, amphibole-rich unit, and felsic unit. All units contain more than 10 vol\% of felsic minerals (quartz and feldspars) and are thus mafic rather than ultramafic. The biotite-amphibole-rich unit is made of 40-10 vol \% of Qtz, 35-10 vol \% of feldspar, 50-5 vol $\%$ of amphibole, $40-5 \mathrm{vol} \%$ of $\mathrm{Bt},<40 \mathrm{vol} \%$ of Chl. The amphibole-rich unit contains $90-40 \mathrm{vol}$ $\%$ of amphibole, $20-5 \%$ of Qtz, 20-5 \% of feldspar, < 10 vol \% of Chl.

The felsic unit is identical to the surrounding quartzo-feldsparthic rocks. Unit names instead of rock names are used in this manuscript because the unit names can best characterize the studied rocks which are highly heterogeneous in mineral abundance.

The decametre to metre lenses of amphibole-rich rock unit occurs parallel to the bedding and form high relief on the weathered surface of the hosting, biotite-amphibole-rich unit. South and north of the Jean Lake, sedimentary rocks are cut by granitic dykes and sills, which originated from the voluminous, two mica granite of 2670-2650 Ma (Percival, 1989; Williams, 1991).

\subsection{Chemical composition and source of the mafic sedimentary rocks}

The mafic sedimentary rocks show significant compositional variations (Table 1). The contents of $\mathrm{SiO}_{2}, \mathrm{Al}_{2} \mathrm{O}_{3}, \mathrm{MgO}$, and $\mathrm{Cr}$ vary from 53.9.wt\% to 65.5.wt\%; 9.8 to $17.9 \mathrm{wt} \%, 3.0$ to $12.5 \mathrm{wt} \%$, and 149 to $866 \mathrm{ppm}$, respectively (Table 1). The contents of $\mathrm{Al}, \mathrm{Ti}, \mathrm{Mg}$, and $\mathrm{Cr}$ form linear arrays with high correlation coefficients $(r>0.95)$, suggesting that they were immobile after sedimentation (Rollinson, 1993). Linear arrays of Ca, Ga, V, Zn, Co, and Ni against these immobile elements suggest that they too were relatively immobile. The plot of two immobile elements, such as $\mathrm{TiO}_{2}$ vs $\mathrm{Al}_{2} \mathrm{O}_{3}$, shows a linear array between the felsic unit and the amphibolerich unit. The biotite-amphibole-rich unit plot between the two units (Fig. 4).

There are three possible causes to form the linear arrays; constant sum effect, hydraulic sorting, and mixing of two end-members. The constant sum effect is rejected because elemental ratios, such as $\mathrm{Ti} / \mathrm{Mg}$ and $\mathrm{Al} / \mathrm{Mg}$, also show linear arrays (Fig. 5a). Hydraulic sorting from a single source was suggested for the cause of compositional variation of sedimentary rocks from the area between the Beardmore and Jean Lake area (Fralick and Kronberg, 1997). The high $\mathrm{Cr}$ content (up to $866 \mathrm{ppm}$ ) and the positive correlation of the contents between $\mathrm{Cr}$ and $\mathrm{Ca}$ require a contribution of chromite and $\mathrm{Ca}$-minerals with similar proportions to the sediments. This is a 
highly unlikely process because two have very different densities. Therefore, the linear correlations of elements are attributed to mixing between two end-member components.

The amphibole-rich unit contains high $\mathrm{MgO}$ (up to $12.5 \mathrm{wt} \%$ ), $\mathrm{Cr}$ (up to $866 \mathrm{ppm}$ ), and high PGE (20 ppb Pt, 17 ppb Pd, 3 ppb Ir). These values are all greater than those of most basaltic igneous rocks, suggesting a contribution from more Mg-rich rocks such as komatiitic basalts, komatiites and mantle peridotites. The latter two possibilities are rejected because komatiites and mantle peridotites contain low $\mathrm{CaO}$ to account for our samples (Fig. 5b). This leaves komatiitic basalts as the source. The amount of the komatiitic basalts is evaluated to be nil in the felsic unit and up to $\sim 90 \%$ in the amphibole-rich unit using the level rule (Fig. 5b).

\section{Deformation in the Jean Lake area and correlation with regional deformation}

Four tectono-metamorphic events have been recognized in the Quetico Subprovince (Williams, 1991, and references therein). The first regional deformation (D1) included slumping, and recumbent folding shortly after sedimentation (2698-< 2690 Ma; Table 4; Sawyer, 1983; Williams, 1991; Zaleski et al., 1999). This event was followed by mainly strike-slip deformation (D2), with lineations plunging east at $10-30^{\circ}$. The D2 deformation resulted in layer-parallel dextral strike-slip shearing and a Subprovince scale west-trending planar (vertical) and linear fabric (Williams, 1991). The subsequent deformation was also transpressive (D3), and produced upright folds (F3) that affected both the bedding and the earlier-formed planar fabrics (Sawyer, 1983; Williams, 1991). The D4 deformation corresponds to minor shearing under a southsoutheast compression (Sawyer, 1983).

The study area shows three stages of deformation. The first stage of deformation in the Jean Lake area produced a foliation defined by $\mathrm{Bt}$ and $\mathrm{St}$. The foliation was later folded during the main deformation event in the area, producing decimetre-scale tight folds with an axial trace of N95 80S. The later foliation, which is defined by Bt, Grt and Sil, is locally oblique to the axial surface because of larger-scale upright folds (Fig. 2). Similar upright folds are common in the Quetico belt and considered to have formed under the regional transpressive D3 deformation (part 4; Williams, 1991), suggesting that this late foliations and upright folds in the Jean Lake area are most like a product of the regional D3 deformation. It implies that the earlier foliation in the Jean Lake area formed during either D1 or D2 regional deformation.

The final deformation in the Jean Lake area produced minor shear zones, which are defined by $\mathrm{Chl} \pm \mathrm{Bt} \pm$ amphibole, strike $\mathrm{N} 110^{\circ}$, dip steeply to the south (Fig. 2). They cut earlier planar and folded fabrics (pre-S3 and S3) and bedding planes and east-trending pre-S3 and S3 foliations rotate into the shear planes, forming hectometre-scale dextral sigmoïds. Z-folds, suggesting dextral strike-slip motion. The location of these asymmetric folds suggests that they are not drag folds of F3 folds, thus unrelated to the D3 deformational event. Z-folds of narrow (up to $1 \mathrm{~cm}$ width) Qtz veins inside the shear zones likely developed during this strike slip deformation (Fig. 6a). The geometry of centimetre-wide kink bands of Chl is also consistent with dextral shearing along a $\mathrm{N} 110^{\circ}$ direction. A conjugate set of the dextral shear is sinistral shear planes striking $\mathrm{N}^{\circ} 0^{\circ}$. Indeed, Pye (1964) identified such shear planes in the Jean Lake area (Fig. 2), confirming that the dextral shear planes formed during north-south compression.

The final deformation in the Jean Lake area corresponds to the regional D4 deformation. Similar deformation features, such as shears and kink bands, formed during the D4 are recorded in the Kashabowie area ( $200 \mathrm{~km}$ south-east of the Jean Lake area; Sawyer, 1983).

\section{Metamorphism in the Jean Lake area}




\subsection{Mineralogy and mineral chemistry}

We conducted a detailed petrographic and thermobarometric study of the felsic and amphibole-rich units, which represent the end members of the compositional variations in the study area. The purpose is to evaluate the thermobarometric evolution of the metasedimentary rocks in the study area and to relate this evolution to the regional deformational events.

\subsubsection{Aluminous unit}

The rocks are defined by the following minerals: $\mathrm{Qtz}+\mathrm{Pl}+\mathrm{Bt}+\mathrm{St} \pm \mathrm{Grt} \pm \mathrm{Sil} \pm \mathrm{Chl} \pm$ $\mathrm{Ilm} \pm$ Tur. Both Qtz and Pl, ranging from 0.05 to $0.1 \mathrm{~mm}$ in size, are anhedral in shape and Pl is homogenous in composition (An25-27). Bt (up to $2 \mathrm{~mm}$ in length) defines the pre-S3 foliation, subsequently deformed by $\mathrm{F} 3$ folds. Later $\mathrm{Bt}, \mathrm{Bt}_{2}$, crystallized parallel to the axial surface, forming the main $\mathrm{S} 3$ foliation. $\mathrm{Bt}_{2}$ in contact with $\mathrm{Grt}$ and $\mathrm{St}$ have similar composition as those in the matrix, with $\mathrm{X}_{\mathrm{Fe}}(=\mathrm{Fe} /(\mathrm{Fe}+\mathrm{Mg})$ atomic ratio) of 0.47-0.49 (Table 2).

St (up to $0.5 \mathrm{~cm} ; 30-5 \mathrm{vol} \%, \mathrm{X}_{\mathrm{Fe}}$ from 0.82 to 0.84 ) is anhedral with corroded rims and belongs to the pre-S3 foliation. Some folded crystals, outline fold limbs of centimetre-scale tight F3 folds (Fig. 6c).

Rare fibrous Sil occurs parallel to the S3 foliation between corroded St and euhedral Bt and Grt (Fig. 6d). The texture suggests the following KFMASH reaction;

$\mathrm{St}+\mathrm{Qtz}+\mathrm{Bt}_{1}=\mathrm{Bt}_{2}+\mathrm{Sil}+\mathrm{Grt}+\mathrm{H}_{2} \mathrm{O}$ (Reaction 1$)$

Grt porphyroblasts $(0.2-1.0 \mathrm{~mm})$ are euhedral, contain Qtz inclusions, and are syn-kinematic with respect to the main S3 foliation. They are solid solutions of $\mathrm{Alm}_{0.72-0.78}, \operatorname{Prp}_{0.10-0.14}, \mathrm{Grs}_{0.03}$ 0.07 and $\mathrm{Sps}_{0.07-0.08}$, and show increasing Alm component toward the rims (Fig. 7). The Sps component decreases towards the $70 \mu \mathrm{m}$ thick rims and starts increasing within the rims (Fig. 7). The bell shaped profile of $\mathrm{Ca}$ and $\mathrm{Mn}$ with a gentle increase in $\mathrm{X}_{\mathrm{Fe}}$ towards the rims is commonly formed during crystal growth (Spear, 1993; Reaction 1). The sharp enrichment of Fe in the outermost rims is probably related to late diffusion of $\mathrm{Fe}$ from $\mathrm{Bt}_{2}$, as suggested by Spear (1993).

$\mathrm{Bt}$ grains are homogeneous, probably because of fast diffusion of elements in Bt (Spear, 1993). $\mathrm{Bt}_{2}$ is partially replaced by Chl.

\subsubsection{Semi-aluminous unit.}

This unit consists of Qtz $+\mathrm{Pl}+\mathrm{Bt} \pm \mathrm{Grt} \pm \mathrm{Chl} \pm \mathrm{Ilm} \pm$ Tur. Anhedral Qtz (0.05-0.1 mm) is predominant and P1 crystals $(0.05-0.2 \mathrm{~mm})$ are anhedral and commonly contain Qtz inclusions.

Individual grains do not show compositional zoning, with $\mathrm{An}_{0.24-0.31}$ (An; $100 *[\mathrm{Ca}] /([\mathrm{Ca}]+[\mathrm{Na}]+[\mathrm{K}]))$ and $\mathrm{An}_{0.14}$ in sample 244 and $\mathrm{An}_{0.22-0.27}$ in sample $262 \mathrm{~b}$.

Bt (0.1-0.3 mm) defines the main S3 foliation and re-crystallized in D4 shear bands (Fig. 6b). Some Bt surrounding Grt define delta micro-structures. Bt grains in contact with Grt have similar compositions as those in the matrix, with $\mathrm{X}_{\mathrm{Fe}}$ of 0.48-0.49.

Euhedral Grt grains (0.3-1.2 mm) contain rounded Qtz inclusions and were rotated by the late dextral strike-slip shear deformation (D4), suggesting crystallization before or during D4. In sample $262 \mathrm{~b}$, Grt crystals $(\sim 1 \mathrm{~mm})$ have Alm component ranging from $0.78-0.84$, whereas Grt $(\sim$ $0.7 \mathrm{~mm}$ ) in sample 244 contains between 0.67 and 0.73 Alm component (Table 2). Sps, Grs and Prp components vary from 0.17 to $0.13,0.06$ to 0.04 and 0.12 to 0.10 , respectively. The Grs and Sps components and $\mathrm{X}_{\mathrm{Fe}}$ decrease from core to rim. The $80 \mu \mathrm{m}$-thick rims record a reverse trend; an increase in Sps and $X_{\mathrm{Fe}}$, and a decrease in Prp component (Fig. 7). 
The bell-shaped zoning pattern suggests that the zoning is a result of crystal growth without subsequent modification by diffusion (Fig. 7). The reverse zoning in the outer rim implies a consumption of Grt during retrogression (Spear, 1993).

Anhedral Kfs crystals identified in one sample occur around Grt porphyroblasts in association with $\mathrm{Chl}$ suggest the following reaction:

$$
\mathrm{Grt}+\mathrm{Bt}+\mathrm{H}_{2} \mathrm{O}=\mathrm{Kfs}+\mathrm{Chl} \text { (Reaction 2) }
$$

Chl crystallized along the dextral shear planes that formed during the south-southeast compression (D4) and replaces Bt under retrograde greenschist facies conditions.

\subsubsection{Amphibole-rich unit}

This unit consists of amphibole $+\mathrm{Pl}+\mathrm{Qtz}+\mathrm{Ilm} \pm \mathrm{Chl} \pm$ Tur. Amphibole $(0.05-1 \mathrm{~mm})$, the predominant mineral, is euhedral to subhedral (Fig. 8) and does not display a preferred orientation. The compositions of the amphiboles plot near the boundary between magnesiohornblende and $\mathrm{Tr}$, following the classification of Leake et al. (1997). They plot an array of solid solutions between Tr-Ts and Tr-Prg (Fig. 9), suggesting a typical Act-Hbl exchange reaction (Spear, 1993). Individual grains in sample 268a show an enrichment of Hbl component whereas those in sample 252a show an enrichment of $\operatorname{Tr}$ component towards the rims (Fig. 10). The P-T evolution reflected on the zoning pattern will be discussed in part 5.3.

$\mathrm{Pl}$ grains are subhedral to anhedral in shape and range in size from 0.1-0.6 $\mathrm{mm}$. They contain inclusions of Qtz and amphibole, and show Ca-enrichment towards the rims ranging from $\mathrm{An}_{0.32}$ to $\mathrm{An}_{0.38}$ in sample $252 \mathrm{a}$ and from $\mathrm{An}_{0.33}$ to $\mathrm{An}_{0.52}$ in sample 268a.

\subsubsection{The felsic unit}

This unit contains $\mathrm{Qtz}+\mathrm{Pl}+\mathrm{Bt} \pm \mathrm{Ilm} \pm$ Tur. It is similar in mineralogy and texture to the surrounding semi-aluminous unit of quartzo-feldsparthic rocks.

\subsection{Thermobarometric methods}

The felsic rocks have low $\mathrm{MnO}$ and $\mathrm{TiO}_{2}$ contents and feldspar is the only $\mathrm{Na}$ - and $\mathrm{Ca}$ bearing phase. Therefore, we used KFMASH petrogenetic grids of Spear and Cheney (1989), together with the aluminosilicate triple point by Richardson et al. (1969) to represent the metamorphic assemblages. We used two Fe-Mg exchange thermometry; Grt-St thermometry of Perchuk (1989) and Grt-Bt thermometry (GARB thermometer) of Pigage and Greenwood (1982) and Williams and Grambling (1990). The classical GARB thermometers of Ferry and Spear (1978) and Indares and Martignole (1985) were not used because Bt compositions in our samples are outside the range accepted for the thermometry $\left(\mathrm{Bt}\right.$ with $\left.\left(\mathrm{Al}^{\mathrm{VI}}+\mathrm{Ti}\right) /\left(\mathrm{Al}^{\mathrm{VI}}+\mathrm{Ti}+\mathrm{Mg}+\mathrm{Fe}\right)<0.15\right)$. Furthermore, the Ti-Al substitution of $\mathrm{Bt}$ in our samples is different from $\mathrm{Bt}$ used by Indares and Martignole (1985). Pressures were estimated using the Grt-Pl-Sil-Qtz (GASP) barometer of Hodges and Crowley (1985) and Koziol and Newton (1988), and the empirical Grt-Pl-Qtz (GPQ) barometer of Hoisch (1990). We also used the THERMOCALC computer program by Powell et al. (1998) in order to identify possible reactions among given end-member phases and to calculate the pressure and temperature of sub-systems.

The amphibole-bearing rocks contain low $\mathrm{TiO}_{2}, \mathrm{MnO}$, and $\mathrm{K}_{2} \mathrm{O}$ and plot on the $\mathrm{ACFM}+\mathrm{SiO}_{2}$ petrogenetic grid defined by Spear (1981). Complementary P-T estimates of the amphibole-rich unit were obtained using the thermometer based on the cation exchange reaction of edenite (Holland and Blundy, 1994). Thermobarometers based on the contents of Ti and Al (VI) in amphibole were not used because of the absence of Zo and Ep in our samples (Raase, 1974; Plyusnina, 1982; Hammarstrom and Zen, 1986). 


\subsubsection{Aluminous unit}

The KFMASH P-T grid of Spear and Cheney (1989) suggests early formation of St at 500 to $700^{\circ} \mathrm{C}$ (Fig. 11). This is consistent with the mineral assemblage of our samples. The second metamorphic stage is characterized by the assemblage of Sil $+\mathrm{Grt}+\mathrm{Bt}$, suggesting a metamorphic condition on the high temperature side of Reaction 1, greater than $600^{\circ} \mathrm{C}$ (Spear and Cheney, 1989; Fig.11). The absence of Kfs and the occurrence of Sil suggest temperatures lower than $800^{\circ} \mathrm{C}$ and pressures between 0.2 and $1 \mathrm{GPa}$. Sample 251 yielded $628 \pm 35{ }^{\circ} \mathrm{C}$ and $0.64 \pm 0.16 \mathrm{GPa}$ using the THERMOCALC program. These results are consistent with the estimate of $600 \pm 70{ }^{\circ} \mathrm{C}$ using the GARB thermometer, and also with $625 \pm 50^{\circ} \mathrm{C}$ and $0.54 \pm 0.09$ GPa using the independent GS thermometer and the GASP barometer. The estimates are all comparable considering uncertainties of the estimated values (Table 3a), but the estimated temperatures represent a minimum because of possible late re-equilibration of $\mathrm{Bt}$ and Grt rims.

\subsubsection{Semi-aluminous unit}

The assemblage of $\mathrm{Grt}+\mathrm{Bt}+\mathrm{Pl}$ suggests a metamorphic temperature greater than $500{ }^{\circ} \mathrm{C}$ (Spear and Cheney, 1989), as Grt can not crystallise on the low temperature side of the reaction:

$$
\mathrm{Fe}-\mathrm{Cld}+\mathrm{Ann}+\mathrm{Qtz}=\mathrm{Alm}+\mathrm{Ms}+\mathrm{H}_{2} \mathrm{O} \text { (Reaction 3) }
$$

In sample 262b, the GARB thermometry and GPQ barometer on Grt cores yielded $610 \pm 70^{\circ} \mathrm{C}$ and $0.56 \pm 0.12 \mathrm{Gpa}$. In sample 244 , Grt cores yielded $585 \pm 70^{\circ} \mathrm{C}$ and $0.71 \pm 0.08 \mathrm{GPa}$, whereas rims with $\mathrm{Pl}$ and $\mathrm{Bt}$ show a retrograde condition of $540 \pm 80^{\circ} \mathrm{C}$ and $0.25 \pm 0.11 \mathrm{GPa}$ (Table 3b).

\subsubsection{Amphibole-rich unit.}

Metamorphic temperatures are estimated using the amphibole-P1 geothermometer (Holland and Blundy, 1994). Amphibole shows compositional zoning from $\mathrm{Hbl}$ in the cores to $\mathrm{Tr}$ in the rims. Tr commonly crystallizes under greenschist facies condition, whereas $\mathrm{Hbl}$ forms under amphibolite facies condition. Therefore, the zoning of amphibole (sample 252a) likely reflects the retrograde path. The core composition of $\mathrm{Hbl}$ and $\mathrm{Pl}$ yields a temperature of $700 \pm 70^{\circ} \mathrm{C}$, comparable to the peak metamorphic temperature $\left(\mathrm{T}>650^{\circ} \mathrm{C}\right)$ for the quartzo-feldspathic rocks.

Amphibole grains, that are free from any evidence of retrogression, in sample 268a record a prograde path, increasing $\mathrm{Hbl}$ component towards the rims. The rims yielded a maximum temperature of $600 \pm 70^{\circ} \mathrm{C}$ using the amphibole-Pl thermometer.

In summary, the rocks in the Jean Lake area underwent a metamorphic event starting with the crystallization of St in the aluminous unit and the increasing $\mathrm{Hbl}$ component in amphiboles in the amphibolite unit. The peak metamorphic P-T, $0.61 \pm 0.10 \mathrm{GPa}$ and $700 \pm 70{ }^{\circ} \mathrm{C}$, was attained during the D3 regional transpressive deformation (Fig. 12). This was followed by retrogression forming Chl and Tr during D4 south-southeast compression at $0.25 \pm 0.11 \mathrm{GPa}, 540 \pm 80^{\circ} \mathrm{C}$ (LPMT event; Fig. 12).

\section{Tectono-metamorphic evolution of the study area and the Quetico Belt}

The first regional deformation (D1) took place shortly after sedimentation and involved burial of sediments, producing moderate P-moderate T (MP-MT) metamorphism (Tabor et al., 1989; Pan and Fleet, 1999). This tectono-metamorphic event was followed by mainly strike-slip deformation (D2). This deformation and subsequent deformation (D2-D3) mainly involved strikeslip deformation, implying no significant change in $\mathrm{P}$ conditions. Therefore, the crystallization of 
St and Hbl-rich amphiboles under the MP-MT metamorphism in the Jean Lake area occurred before the regional D2 transpressional deformation. It is most likely related to the regional D1.

The second stage deformation in the Jean Lake area, which corresponds to regional D2-D3, is accompanied by the peak metamorphic. The final deformation in the Jean Lake area includes local shearing during south-southeast compression, accompanied by LP-MT metamorphism. The metamorphic condition, $0.25 \mathrm{GPa}$ and $540^{\circ} \mathrm{C}$ in the Jean Lake area, is in agreement with the conditions expected from the Subprovince-wide metamorphism. There is a systematic increase in metamorphic conditions, from $0.2 \mathrm{GPa}$ and $500^{\circ} \mathrm{C}$ at the U.S.A.-Canada border in the west to 0.5$0.6 \mathrm{GPa}$ and $780^{\circ} \mathrm{C}$ in the eastern part of the Quetico belt (Pirie and Mackasey, 1978; Percival, 1989). Greenschist facies retrogression is recorded at the end of D4 deformation in the Jean Lake area. Similar retrogression is observed in many other places in the Quetico belt (Percival, 1989; Pan et al., 1994; Pan and Fleet, 1999).

The last two regional deformation events (D3 and D4) were described by Sawyer (1983) and Williams (1991), but their timing is not well established. Furthermore, the timing of the regional D2 (and then D1) deformation and its relationship with regional metamorphism are in debate. Based on ages of intrusive rocks and detailed structural study in Shebandowan and adjoining Quetico belt (Fig. 2), Percival (1989 and references therein) suggested the regional D2 bracketed between 2689 and $2684 \mathrm{Ma}$ and the LP-MT event at 2671-2667 Ma. On the other hand, Pan et al. (1998) suggested that the regional D2 deformation ended after 2666 Ma because pegmatitic rocks of this age were concordant to the penetrative S2 foliation. This implies that the D2 was associated with the regional metamorphism. This is not consistent with our data from the Jean Lake area, where the LP-MT metamorphism was synchronous with the D4 deformation. To confirm this time relationship, we dated monazite that crystallized during the LP-MT metamorphic stage (D4).

\section{Dating of monazite}

Thirty six grains of monazite were examined in sample 251. Monazite shows no compositional zoning, contains high $\mathrm{U}$ (up to $0.8 \mathrm{wt} \%$ ), Th (up to $5 \mathrm{wt} \%$ ) and light rare earth elements (REE). Chondrite-normalized REE patterns of all grains are similar, suggesting a single population of monazite (Fig. 13). The age was calculated from the concentration of $\mathrm{U}, \mathrm{Th}$, and $\mathrm{Pb}$ assuming no $\mathrm{Pb}$ at the time of crystallization following the method of Montel et al. (1996; see caption for Fig. 14). The calculated mean age is $2667 \pm 20 \mathrm{Ma}$ with a mean square of weighted deviates (MSWD) of 0.36. The error is estimated following the method described in Montel et al. (1996). The narrow range of MSWD supports a single generation population of monazite in the sample (Fig. 14).

\section{Discussion}

\subsection{Pressure-temperature-time path}

The age of $2667 \pm 20 \mathrm{Ma}$ for the D4 and LP-MT metamorphism is in good agreement with the time span of 2671-2667 Ma suggested by Percival and Sullivan (1988) and 2668 \pm 6 Ma of the $\mathrm{U}-\mathrm{Pb}$ age of metamorphic titanite reported by Pettigrew et al. (2001). For the D2 deformation, we adopt 2689-2684 Ma suggested by Percival (1989). The pegmatite of $2666 \pm 1$ Ma dated by Pan et al, (1998) likely intruded along the pre-existing S2 foliation.

Combining our data with those of previous workers, we propose the P-T-t path for the central part of the Quetico metasedimentary belt described below. The rocks were buried to form a MPMT mineral assemblage under amphibolite facies P-T conditions during the D1 shortly after the 
sedimentation bracketed between 2698 and <2690 Ma (Zaleski et al., 1999). Transpressive deformation (D2-D3) started at $2689 \mathrm{Ma}$ and was accompanied by peak metamorphic conditions of $\mathrm{P}=0.61 \pm 0.10 \mathrm{GPa}$ and $\mathrm{T}=700 \pm 70{ }^{\circ} \mathrm{C}$. The subsequent south-southeast compression, $\mathrm{D} 4$, was accompanied by east-west extrusion under LP-MT metamorphic conditions $(0.25 \pm 0.11 \mathrm{GPa}$, $540 \pm 80{ }^{\circ} \mathrm{C}$ ) at 2671-2667 Ma (Fig. 12). This deformation likely continued under retrograded greenschist-facies conditions, forming lineations of $\mathrm{Chl}$ and $\mathrm{Tr}$.

8.2 Tectonic setting of the sedimentation of the Quetico belt

A variety of tectonic settings have been proposed for the deposition of the sediments in the Quetico belt. We briefly present the evidence for and against several possible settings.

Ensialic basin

Given the elongate shape of the Quetico metasedimentary belt, an aborted rift basin in sialic crust was suggested for the depositional environment (Percival, 1989). As discussed by Percival (1989) and Williams (1990), the turbiditic character of the Quetico sedimentary rocks is markedly different from alluvial conglomeratic sequences that commonly develop in a continental extensional basin.

Back-arc basin or intra-arc basin

The evidence against this model is essentially the same as for the ensialic rift environment described above. In addition, the Quetico belt does not contain rift-related mafic igneous rocks that are common in a back-arc or intra-arc basin.

Forearc setting

This was first suggested by Devaney and Williams (1988) based on a sedimentologicalstructural study in the Beardmore-Geraldton area (Fig. 2) in the southern margin of the Wabigoon Subprovince. They outlined north-dipping thrust slices of volcanic-sedimentary rocks and interpreted the area as a forearc basin in an accretion model. Sediments in modern forearc basins are thin (Lallemand, 1999), which is not consistent with the observed $20 \mathrm{~km}$ of burial corresponding to MP-MT metamorphism established shortly ( $<9 \mathrm{My})$ after sedimentation.

Accretionary prism

This model, proposed by Percival (1989) and Williams (1990), suggests that submarine fans and abyssal turbidites were first deformed during their accretion onto the active Wabigoon arc (D1) and later during docking to the Wawa arc (D2-D3). The younging age of sedimentation toward the south part of the Quetico belt (Zaleski et al., 1999) is compatible with a southward propagation of the active front as observed with a north dipping subduction (Platt, 1986). An oblique component of this convergence likely contributed to the observed transpressional structures, dextral wrench zones, and transcurrent faults along subprovince boundaries. Thermal relaxation after cessation of subduction could account for the late LP-MT metamorphism.

Seismic reflection profiles from the Superior Province illustrates crustal reflections dipping toward the centre of the craton and the remnant of the subducting lithosphere from within the crust to 80-100 $\mathrm{km}$ in the mantle (Ludden et al., 1993; Calvert et al., 1995). Island arcs were continuously accreted to a continent to the north through subduction and collision. This is further supported by petrological and structural studies in the Superior Province (Desrochers et al., 1993; Tomlinson et al., 1996; Davis, 1998). Thus, we suggest that an accretionary prism setting best explains the sedimentologic, metamorphic, tectonic and geophysics characterics of the Quetico belt.

8.3 Source and evolution of the Quetico accretionary prism 
The sedimentary rocks in the Jean Lake area formed by mixing of quartzo-feldspathic rocks and komatiitic basalts. Three types of possible geological setting are considered for the komatiitic basalts; an oceanic island that accreted to the Quetico belt, igneous rocks in the Quetico belt, and the adjacent southern Wabigoon Subprovince. An oceanic island and a volcano inside the Quetico belt are unlikely simply because there are no komatiites or komatiitic basalts in the Quetico belt. There are abundant mafic igneous rocks in the southern Wabigoon subprovince that are contemporaneous with the sedimentation of the Quetico sediments. They include a suite of sanukitoids of $\sim 2690 \mathrm{Ma}$ in the Wabigoon Subprovince (Stern and Hanson, 1991; Stevenson et al., 1999), and voluminous mafic-ultramafic rocks $\sim 2692 \mathrm{Ma}$ in the southern Wabigoon belt along the boundary with the Quetico belt (Sutcliffe et al., 1989; Blackburn et al., 1991; Pettigrew and Hattori, 2002).

High contents of $\mathrm{MgO}$ and $\mathrm{CaO}$ suggest a proximal source, since these elements are easily leached during weathering and transportation (Nesbitt and Young, 1989). Immature sediments may be formed during sudden uplift and erosion of a source terrane, or by discharge of pyroclastic material from a volcano. The compositions of the mafic sedimentary rocks are still too immature to have originated from such a distal source as the southern Wabigoon Subprovince. The study of modern accretionary prisms suggest that the sediments may have deposited close to the Wabigoon Subprovince.

In modern accretionary prisms, sediments are thickened through repeated underplating and near-horizontal thrusting (Platt, 1986; Lallemand, 1999; Hashimoto and Kimura, 1999). Continued underplating at the base of the wedge is compensated by extension in the shallow part of the wedge (Platt, 1986; Lallemand, 1999). This extension in the rear of the prism causes lateral movement of material and thrusting toward the prism front (Platt, 1986; Fig. 15). Our structural analysis in the Jean Lake area shows that the mafic sediments were most likely buried during the D1 deformation under compressional regime. Taking the structural development of modern accretionary wedges as an example, we suggest that the rocks in the Jean Lake area were deposited close to the Quetico-Wabigoon boundary and were displaced towards the south, subsequently buried by rapid underthrusting along a MP-MT metamorphic gradient to amphibolite facies P-T conditions. Subsequent dominant dextral transpressive deformation (D2D3) displaced the sedimentary rocks to the west from the original depositional site. The dextral component during D2-D3 was likely caused by strain partitioning in an oblique convergent system as described in many modern subduction zones, such as the Ryukyu, Higurangi, Aleutian, and western North American subduction zones (Lallemand, 1999). This is also consistent with an earlier suggestion by Percival (1989) that the Wawa arc collided obliquely with the Wabigoon arc to the north.

The rocks were then uplifted during the D4 deformation. This exhumation was likely accompanied by the development of LP-MT metamorphism and voluminous granitic plutonism. This has been interpreted previously as a result of thermal relaxation (Percival, 1989; Williams, 1991).

\subsection{Comparison with modern subduction zones}

Our data suggest the burial of sedimentary rocks to a depth of about $20 \mathrm{~km}$ and their metamorphism up to amphibolite facies conditions in less than 9 M.y., and their exhumation up to LP-MT conditions within about 15 M.y. In Phanerozoic orogenic belts, the typical burial rate of sediments in prisms is about 3 to $8 \mathrm{~cm} / \mathrm{yr}$ (Demets et al., 1990) and their exhumation rate is about 0.2 to $1 \mathrm{~mm} / \mathrm{yr}$ (Duchêne et al., 1997; Schwartz et al., 2000; De Sigoyer et al., 2000). Using these 
burial and exhumation rates, our P-T path suggests that the Quetico rocks would have been buried in less than $\sim 1$ M.y. and exhumed within 12 to 60 M.y. The estimates from the Quetico metasedimentary rocks are thus compatible with those from modern subduction zones, suggesting that the Neoarchean tectonic regime was essentially similar to the modern analogs.

Modern subduction zones commonly contain HP-LT metamorphic rocks, such as blueschists and eclogites. They formed under low geothermal gradients, $\sim 10^{\circ} \mathrm{C} / \mathrm{km}$ (Fig. 12; Ernst, 1988; Ernst and Liou, 1999; Schwartz et al., 2000). Like many other Archean sedimentary terranes, the Quetico belt does not contain HP-LT rocks. The lack of such metamorphic rocks in Archean terranes has been in debate (e.g., De Wit, 1998). This may be attributed to high geothermal gradients $\left(\sim 30^{\circ} \mathrm{C} / \mathrm{km}\right)$ during Archean time possibly caused by local effects such as magma emplacement and ridge subduction, as proposed to account for high geothermal gradients of several Phanerozoic accretionary prisms (Sakaguchi, 1999). Upwelling of magmas may be supported by the occurrence of small, yet numerous intrusions in the belt including $2680+-1 \mathrm{Ma}$ alkaline igneous rocks (Hattori and Percival, 1999).

\section{Conclusion}

Our study in the Jean Lake area suggests that the Quetico sedimentary rocks formed in an accretionary prism above a north-dipping slab subducting underneath the Wabigoon Subprovince. Oblique convergence of the prism and the Wawa volcanic belt resulted in transpressional deformation within the prism. The geodynamic setting and tectono-metamorphic evolution of the accretionary prism is comparable to those of modern examples. The sedimentary rocks were buried along a gradient of about $30^{\circ} \mathrm{C} / \mathrm{km}$, which is significantly higher than modern counterparts $\left(10^{\circ} \mathrm{C} / \mathrm{km}\right)$. The lack of HP-LT rocks, such as blueschists, in the Quetico belt is attributed to such high geothermal gradients.

\section{Acknowledgements}

We thank G. Maheo and P. Goncalves for discussions, B. Lassen, N. T. Pettigrew and P. Chantigny for discussions and assistance in the field, M. Veschambre of Blaise Pascal University in Clermont-Ferrand for his technical assistance with the electron microprobe, Ron Hartree and Monika Wilk-Alemany of the University of Ottawa for XRF and trace element analysis, and George Mrazek of the University of Ottawa and M. Clermont of the University of Lyon1 for making thin sections. We thank John A. Percival of the Geological Survey of Canada and Ralph Kretz, Flemming Mengel, and J. Martignole for their helpful comments. 


\section{References}

Ayer, J.A., 1999. Petrogenesis and Tectonic Evolution of the Lake of the Woods Greenstone Belt, Western Wabigoon Subprovince, Ontario, Canada. Unpubl. PhD thesis, University of Ottawa, Canada. 207 pp.

Ballantyne, P., 1992. Petrology and geochemistry of the plutonic rocks of the Halmahera ophiolite, eastern Indonesia, an analogue of modern oceanic forearcs. In: Parson, L.M., Murton, B.J., Browning, P. (Eds.), Ophiolites and their Modern Oceanic Analogues. Geological Society Special Publication No. 60, pp. 179-202.

Blackburn, C.E., Johns, G.W., Ayer, J., Davis, D.W., 1991. Wabigoon Subprovince. In: Thurston, P.C., Williams, H.R., Sutcliffe, R.H., Stott, G.M. (Eds.), Geology of Ontario. Ontario Geological Survey Special Vol. 4. Ontario Geological Survey, Ontario, Canada, pp. 303381.

Calvert, A.J., Sawyer, E.W., Davis, D.W., Ludden, J.N., 1995. Archean subduction inferred from seismic image of a mantle suture in the Superior Province. Nature 375, 670-674.

Card, K.D., 1990. A review of the Superior Province of the Canadian Shield, a product of Archean accretion. Precambrian Res. 48, 99-156.

Cook, F.A., Van der Velden, A.J., Hall, K.W., Roberts, B.J., 1999. Frozen subduction in Canada's Northwest Territories: Lithoprobe deep lithospheric reflection profiling of the western Canadian Shield. Tectonics 18, 1-24.

Davis, D.W., Pezzutto, F., Ojakangas, R.W., 1990. The age and provenance of metasedimentary rocks in the Quetico Subprovince, Ontario, from single zircon analyses: implications for Archean sedimentation and tectonics in the Superior Province. Earth Planet. Sci. Lett. 99, 195-205.

Davis, D.W., 1998. Speculation on the formation and crustal structure of the Superior Province from U-Pb geochronology. In: Helmstaedt, H., Harrap, R. (Eds.), Western Superior Lithoprobe 1998 annual meeting: progress reports, technical communications, and abstracts. University of British Colombia, Lithoprobe Secretariat (for the) Canadian Lithoprobe Program, Vancouver, BC, Canada, pp. 21-28.

Demets, C., Gordon, R.G., Argus, D.F., Stein, S, 1990. Current plate motions. Geophys. J. Int. $101,425-478$.

De Sigoyer, J., Chavagnac, V., Blichert-Toft, J., Villa, I.M., Luais, B., Guillot, S., Cosca, M., Mascle, G., 2000. Dating the Indian continental subduction and collisional thickening in the northwest Himalaya: Multichronology of the Tso Morari eclogites. Geology 28, 487490.

Desrochers, J.P., Hubert, C., Ludden, J.N., Pilote, P., 1993. Accretion of Archean oceanic plateau fragments in the Abitibi greenstone belt, Canada. Geology 21, 451-454.

Devaney, J.R., Williams, H.R., 1988. Evolution of an Archean Subprovince boundary: A sedimentological and structural study of part of the Wabigoon-Quetico boundary in northern Ontario. Can. J. Earth Sci. 26, 1013-1026.

De Wit, M.J., 1998. On Archean granites, greenstones, cratons and tectonics: does the evidence demand a verdict? Precambrian Res. 91, 181-226.

Duchêne, S., Lardeaux, J.M., Albarède, F., 1997. Exhumation of eclogites: insights from depthtime path analysis. Tectonophysics $280,125-140$.

Ernst, W.G. 1988. Tectonic history of subduction zones inferred from retrograde blueschist P-T paths. Geology 16, 1081-1084. 
Ernst, W.G., Liou, J.G., 1999. Overview of UHP metamorphism and tectonics in well-studied collisional orogens. Internat. Geol. Reviews 41, 477-493.

Ferry, J.M., Spear, F.S., 1978. Experimental calibration of the partitioning of Fe and $\mathrm{Mg}$ between biotite and garnet. Contrib. Mineral. Petrol. 66, 113-117.

Fralick, P.W., Kronberg, B.I., 1997. Geochemical discrimination of clastic sedimentary rock sources. Sediment. Geol. 113, 111-124.

Fralick, P.W., Wu, J., Williams, H.R., 1992. Trench and slope basin deposits in an Archean metasedimentary belt, Superior Province, Canadian Shield. Can. J. Earth Sci. 29, 25512557.

Fryer, P., Ambos, E.L., Hussong, D.M., 1995. Origin and emplacement of Mariana forearc seamounts. Geology 13, 774-777.

Hamilton, W.B., 1998. Archean magmatism and deformation were not products of plate tectonics. Precambrian Res. 91, 143-179.

Hammarstrom, J.M., Zen, E-An, 1986. Aluminum in hornblende: An empirical igneous geobarometer. Am. Mineral. 71, 1297-1313.

Hashimoto, Y., Kimura, G., 1999. Underplating processes from melange formation to duplexing; example from the Cretaceous Shimanto belt, Kii Peninsula, Southwest Japan. Tectonics 18, 92-107.

Hattori, K.H., Percival, J.A., 1999. Archean carbonate-bearing alkaline igneous complexes of the western Quetico metasedimentary belt, Superior Province, Ontario. Geol. Surv. Can. Curr. Res. 1999-C, 221-231.

Hodges, K.V., Crowley, P.D., 1985. Error estimation and empirical geothermobarometry for pelitic systems. Am. Mineral. 70, 702-709.

Hoisch, T.D., 1990. Empirical calibration of six geobarometers for the mineral assemblage Qtz + muscovite + biotite + plagioclase + garnet. Contrib. Mineral. Petrol. 104, 225-234.

Holland, T., Blundy, J., 1994. Non-ideal interactions in calcic amphiboles and their bearing on amphibole-plagioclase thermometry. Contrib. Mineral. Petrol. 116, 433-447.

Indares, A., Martignole, J., 1985. Biotite-garnet geothermometry in the granulite facies: the influence of Ti and $\mathrm{Al}$ in biotite. Am. Mineral. 70, 272-278.

Koziol, A.M., Newton, R.C., 1988. Redetermination of the anorthite breakdown reaction and improvement of the plagioclase-garnet- $\mathrm{Al}_{2} \mathrm{SiO}_{5}$-Qtz geobarometer. Am. Mineral. 73, 216223.

Kretz, R., 1983. Symbols for rock-forming minerals. Am. Mineral. 68, no.1-2, 277-279.

Lallemand, S., 1999. La subduction océanique. Gordon and Breach Science Publishers, Amsterdam, 193 pp.

Lassen, B., Hattori, K., Percival, J.A., 2000. Late Archean alkaline magmatism in the western Quetico belt, Superior Province, Ontario. Geol. Surv. Can. Curr. Res. 2000-C21, 6 pp.

Leake, B.E., Woolley, A.R., Birch, W.D., Gilbert, M.C., Grice, J.D., Hawthorne, F.C., Kato, A., Kisch, H.J., Krivovichev, V.G., Linthout, K., Laird, J., Mandarino, J., Maresch, W.V., Nickel, E.H., Rock, N.M.S., 1997. Nomenclature of amphiboles. Report of the Subcommittee on Amphiboles of the International Mineralogical Association Commission on New Mineral Names. Eur. J. Mineral. 9, 623-651.

Ludden, J.N., Hubert, C., Barnes, A., Milkereit, B., Sawyer, E., 1993. A three dimensional perspective on the evolution of Archean crust: LITHOPROBE seismic reflection images in the southwestern Superior Province. Lithos 30, 357-372. 
Montel, J.M., Veschambre, S.F.M., Nicollet, C., Provost, A., 1996. Electron microprobe dating of monazite. Chem. Geol. 131, 37-53.

Nesbitt, H.W., Young, G.M., 1989. Formation and diagenesis of weathering profiles. J. Geology. 97, 129-147.

Nicolas, A., 1989. Structures and dynamics of Oceanic Lithosphere. Klüwer Academic Publishers, New York. 188 pp.

Ojakangas, R.W., 1985. Review of Archean clastic sedimentation, Canadian Shield: major felsic volcanic contributions to turbidite and alluvial fan-fluvial facies associations. In: Ayres, L.D., Thurston, P.C., Card, K.D., Weber, W. (Eds.), Evolution of Archean Supracrustal Sequences. Geol. Assoc. Can. Spec. Pap. 8, 23-48.

Ontario Geological Survey, 1991. Bedrock Geology of Ontario, west-central sheet; Ontario Geological Survey, Map 2542 (scale of 1:1 000 000).

Pan, Y., Fleet, M.E., 1999. Kyanite in the western Superior Province of Ontario: implication for Archean accretionary tectonics. Can. Mineral. 37, 359-373.

Pan, Y., Fleet, M.E., Williams, H.R., 1994. Granulite-facies metamorphism in the Quetico Subprovince, north of Manitouwadge, Ontario. Can. J. Earth Sci. 31, 1427-1439.

Pan, Y., Fleet, M.E., Heaman, L., 1998. Thermo-tectonic evolution of an Archean accretionary complex: U-Pb geochronological constraints on granulites from the Quetico Subprovince, Ontario, Canada. Precambrian Res. 92, 117-128.

Perchuk, L.L., 1989. Internal consistency of some Fe-Mg geothermometers based on Nernst law, a revision (In Russian, with English Abstr.). Geokhimiya 5, 611-622.

Percival, J.A., 1989. A regional perspective of the Quetico accretionary complex, Superior Province, Canada. Can. J. Earth Sci. 26, 677-693.

Percival, J.A., Sullivan, R.W., 1988. Age constraints on the evolution of the Quetico Belt, Superior Province, Canada. Geol. Surv. Can., Paper 88-2, 97-108.

Pettigrew, N.T., Hattori, K.H. and Percival, J.A., 2001, The Quetico intrusions, Archean examples of Alaskan/Ural type intrusions. Abstract of the Western Superior Transect Lithoprobe Meeting.

Pigage, L.C., Greenwood, H.J., 1982. Internally consistent estimates of pressure and temperature: the staurolite problem. Am. J. Sci. 282, 943-969.

Pirie, J., Mackasey, W.O., 1978. Preliminary examination of regional metamorphism in parts of Quetico metasedimentary belt, Superior Province, Ontario. In: Fraser, J.A., Heywood, W.W. (Eds.), Metamorphism in the Canadian Shield. Geol. Surv. Can., Ottawa, Canada, Paper 78-10, pp. 37-48.

Plyusnina, L.P., 1982. Geothermometry and geobarometry of plagioclase-hornblende bearing assemblages. Contrib. Mineral. Petrol. 80, 140-146.

Platt, J.P., 1986. Dynamics of orogenic wedges and the uplift of high-pressure metamorphic rocks. Geol. Soc. Am. Bull. 97, 1037-1053.

Powell, R., Holland, T., Worley, B., 1998. Calculating phase diagrams involving solid solutions via non-linear equations with examples using THERMOCALC. J. Metamorph. Geol. 16, 577-588.

Pye, E.G., 1964. Map 2056 (scale of 1:63360), Georgia Lake area, Thunder Bay District. Ontario Department of Mines, Toronto.

Raase, P., 1974. Al and Ti contents of hornblende, indicators of pressure and temperature of regional metamorphism. Contr. Mineral. Petrol. 45, 231-236. 
Richardson, S.W., Gilbert, M.C., Bell P.M., 1969. Experimental determination of kyaniteandalusite and andalusite-sillimanite equilibria: the aluminum silicate triple point. Am. J. Sci. 267, 259-272.

Rollinson, H. R., 1993. Using geochemical data; evaluation, presentation, interpretation. Longman Scientific \& Technical, Harlow, United Kingdom (GBR), 352 pp.

Sakaguchi, A., 1999. Thermal maturity in the Shimanto accretionary prism, southwest Japan, with the thermal change of the subducting slab: fluid inclusion and vitrinite reflectance study. Earth Planet. Sci. Lett. 173, 61-74.

Sawyer, E.W., 1983. The structural history of a part of the Archean Quetico metasedimentary belt, Superior Province: Canada. Precambrian Res. 22, 271-294.

Schwartz, S., Lardeaux, J.M., Guillot, S., Tricart, P., 2000. The diversity of eclogitic metamorphism in the Monviso ophiolitic complex, western Alps, Italy. Geodin. Acta 13, 169-188.

Spear, F.S., 1981. An experimental study of hornblende stability and compositional variability in amphibolite. Am. J. Sci. 281, 697-734.

Spear, F.S., 1993. Metamorphic Phase Equilibria and Pressure-Temperature-Time Paths. Mineral. Soc. Am. Monogr., New York, 799 pp.

Spear, F.S., Cheney, J.T., 1989. A petrogenetic grid for pelitic schists in the system $\mathrm{SiO}_{2}-\mathrm{Al}_{2} \mathrm{O}_{3}$ FeO-MgO- $\mathrm{K}_{2} \mathrm{O}-\mathrm{H}_{2} \mathrm{O}$. Contrib. Mineral. Petrol. 101, 149-164.

Stern, R.A., Hanson, G.N., 1991. Archean high Mg granodiorite; a derivation of light rare earth element-enriched monzodiorite or mantle origin. J. Petrol. 32, 201-238.

Stevenson, R., Henry, P., Gariepy, C., 1999. Assimilation-fractional crystallization origin of Archean sanukitoid suites; Western Superior Province, Canada. Precambrian Res. 96, 8399.

Sutcliffe, R.H., Sweeny, J.M., Edgar, A.D., 1989. The Lac des Iles complex, Ontario: Petrology and platinum-group elements mineralization in an Archean mafic intrusion. Can. J. Earth Sci. 26, 1408-1427.

Tabor, J.R., Hudleston, P.J., Magloughlin, J., 1989. Metamorphism of the Quetico supracrustals north of the Vermillon granitic complex, northern Minnesota (abstr.). Geol. Ass. Canad. , Mineral. Ass. Canad., Canad. Geophys. Union, Joint Annual Meeting, Vol. 14, pp.38.

Thurston, P.C., Chivers, K.M., 1990. Secular variation in greenstone sequence development emphasizing Superior Province, Canada. Precambrian Res. 46, 21-58.

Tomlinson, K.Y., Hall, R.P., Hughes, D.J., Thurston, P.C., 1996. Geochemistry and assemblage accretion of metavolcanic rocks in the Beardmore-Geraldton greenstone belt, Superior Province. Can. J. Earth Sci. 33, 1520-1533.

Williams, H.R., 1988. Geological Studies in the Wawa, Quetico, and Wabigoon Subprovinces, with emphasis on structure and tectonic development. In: Summary of Field Work and Other Activities 1988. Ont. Geol. Surv., Miscellaneous Paper 141, Toronto, pp. 169-172.

Williams, H.R., 1990. Subprovince accretion tectonics in the south-central Superior Province. Can. J. Earth Sci. 27, 571-581.

Williams, H.R., 1991. Quetico Subprovince. In: Thurston, P.C., Williams, H.R., Sutcliffe, R.H., Stott, G.M. (Eds.), Geology of Ontario. Ontario Geological Survey Special Vol. 4. Ont. Geol. Surv., Ontario, Canada, pp. 383-403.

Williams, M.L., Grambling, J.A., 1990. Manganese, ferric iron, and the equilibrium between garnet and biotite. Am. Mineral. 75, 886-908. 
Yamamoto, K., Masutani, Y., Nakamura, N., Ishii, T., 1992. REE characteristics of mafic rocks from a fore-arc seamount in the Izu-Ogasawara region, Western Pacific. Geochem. J. 26, 411-423. 


\section{FIGURE CAPTIONS}

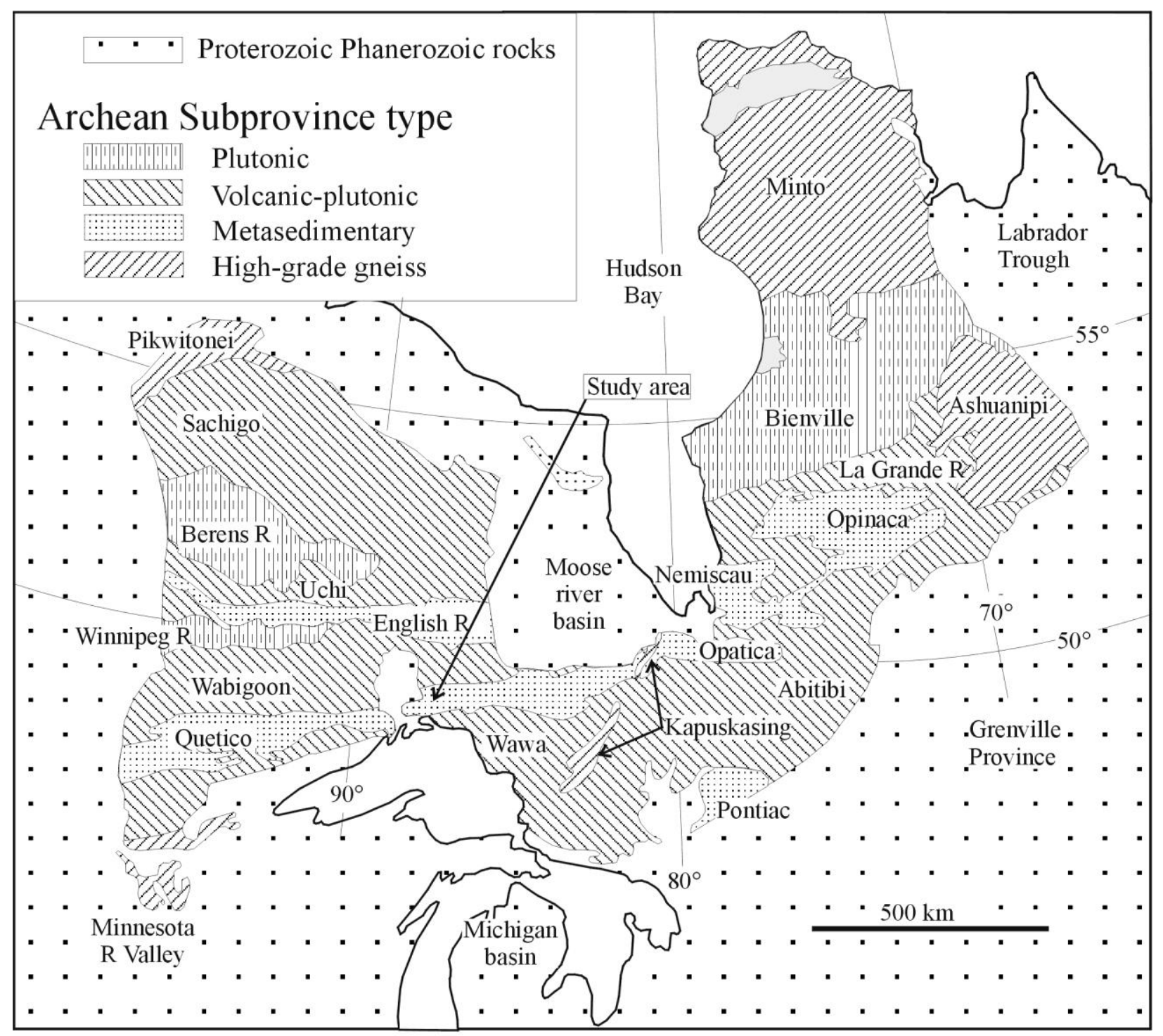

Modified after Card, 1990

Figure 1. Simplified geological map of the Superior Province with the names and locations of Subprovinces and the location of the study area shown in Figure 2, modified after Card (1990). 


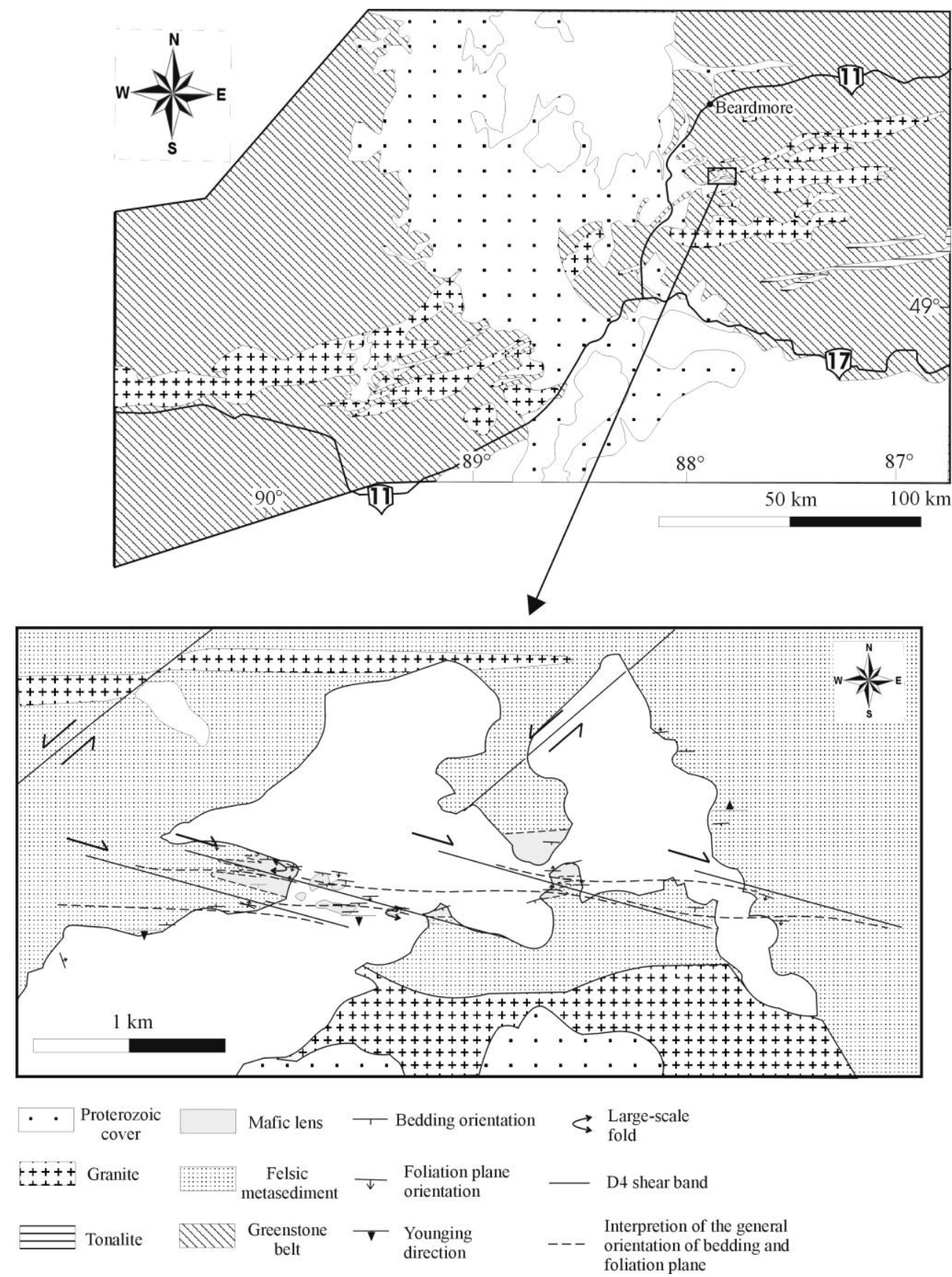

Figure 2a. Geological map of the central Quetico metasedimentary belt (modified after map 2542 from Ontario Geological Survey, 1991) and the location of the study area.

2b. Geological map of the study area (modified after map 2056 by Pye (1964)).- - If you have added your structural measurements, you should say so. 
a

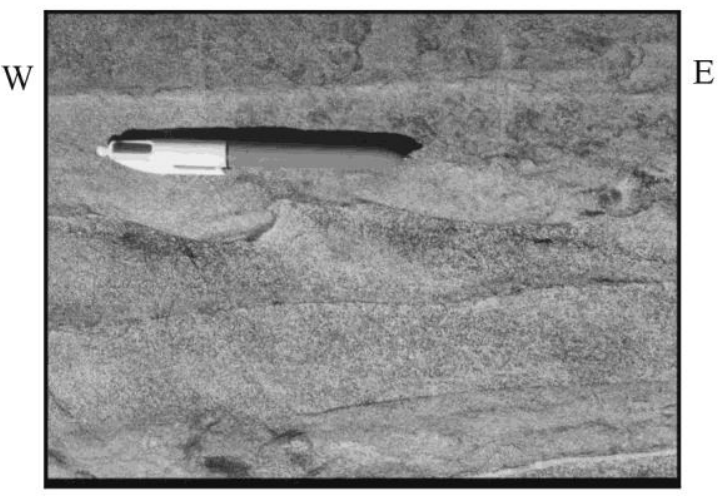

$\mathrm{C}$

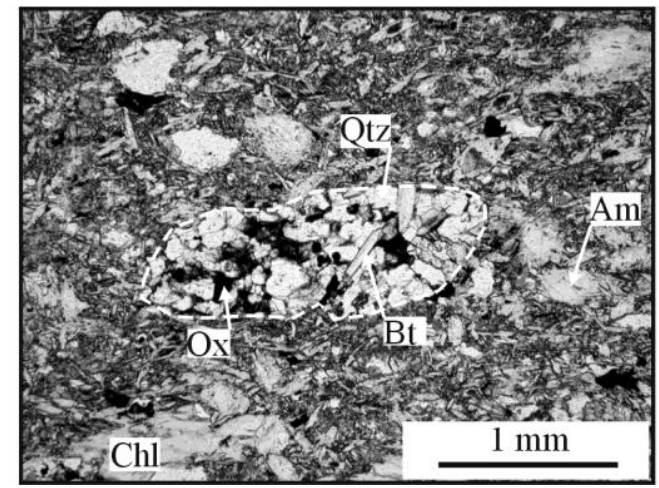

b

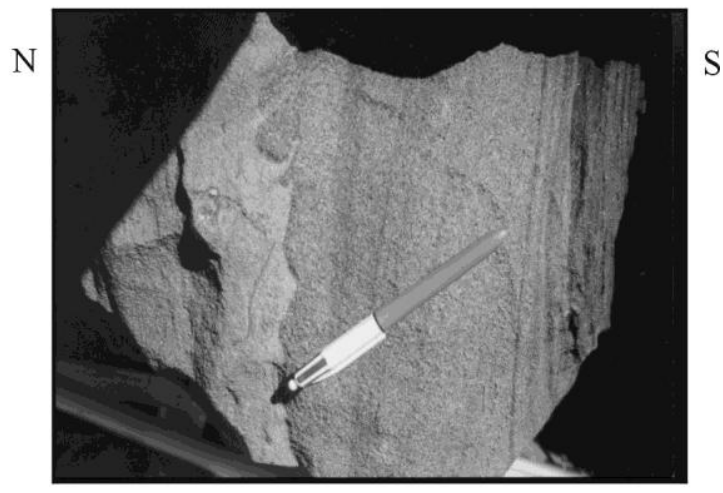

Figure 3a: Flame structure in the quartzo-feldspathic host rock. Pen is $14 \mathrm{~cm}$ long.

3b. Loading structure in the biotite-amphibole-rich unit.

3c. Photomicrograph showing a quartz-rich clast in the amphibole-rich unit.

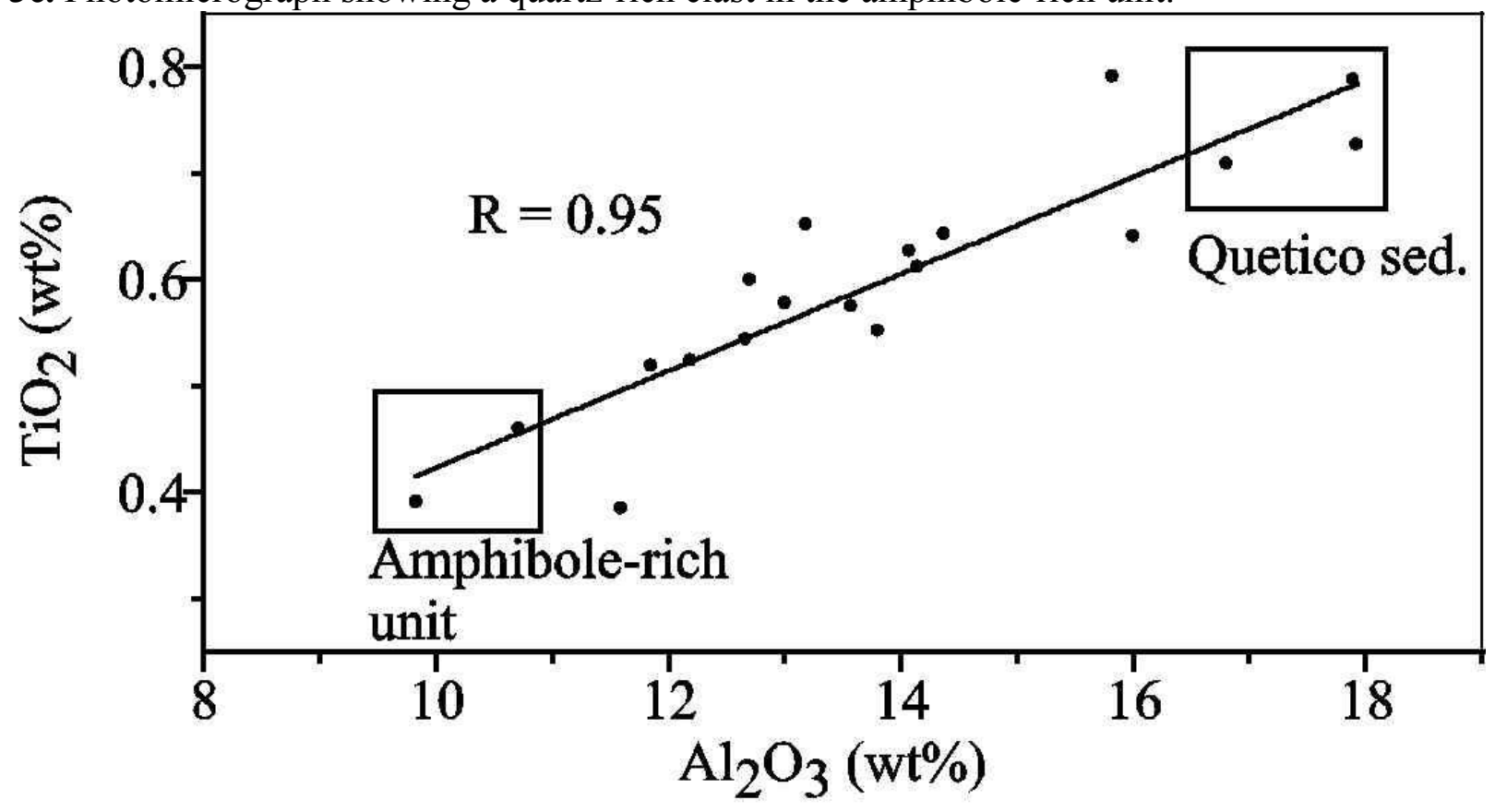


Figure 4. $\mathrm{TiO}_{2}$ vs. $\mathrm{Al}_{2} \mathrm{O}_{3} \mathrm{wt} \%$ of mafic rocks in the Jean Lake area. Circles correspond to the rocks from the biotite-amphibole-rich unit, triangle to the rocks from the amphibole-rich unit, squares to the felsic unit in the mafic lens and the quartzo-feldsparthic rocks surrounding the mafic lens.
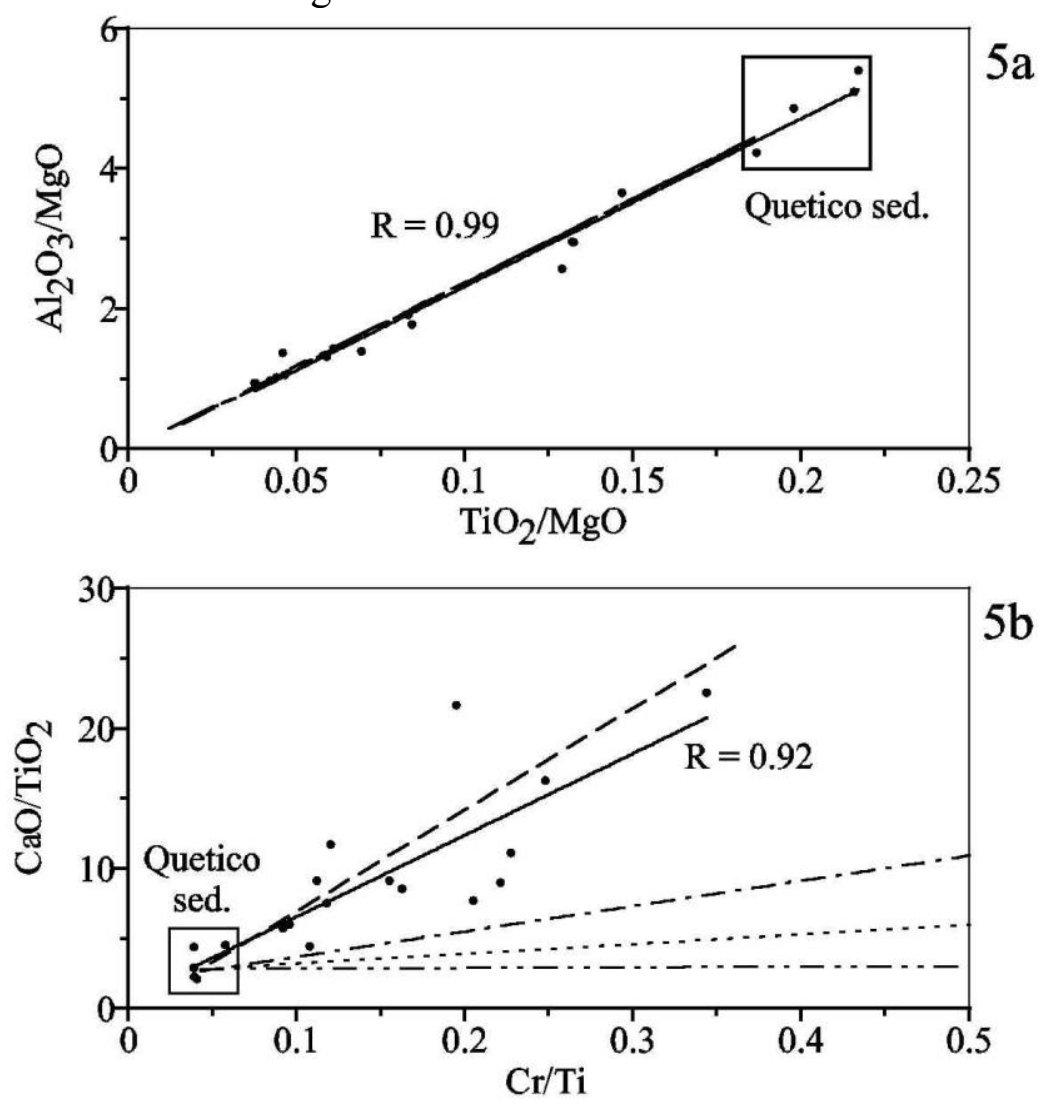

Figure 5a. Weight ratios of $\mathrm{Al}_{2} \mathrm{O}_{3} / \mathrm{MgO}$ vs $\mathrm{TiO}_{2} / \mathrm{MgO}$ for rocks from the mafic lens in the Jean Lake area. The regression line (solid line) of sedimentary rocks from the mafic lens compared to various mixing lines between an averaged composition of the Quetico felsic sedimentary rocks (host rocks and felsic-unit rocks) and possible ultramafic and mafic rocks; komatiitic basalt (dashed line; Ayer, 1999), komatiite (dash-dot line; Ayer, 1999) in the southern Wabigoon Subprovince, harzburgite (dash-double-dot line; Yamamoto et al., 1992) and lherzolite (dotted line; Ballantyne, 1992).

5b. Weight ratios of $\mathrm{CaO} / \mathrm{TiO}_{2}$ vs $\mathrm{Cr} / \mathrm{Ti}$ for rocks from the mafic lens in the Jean Lake area. Lines are described in Figure 5a. 
$6 a$

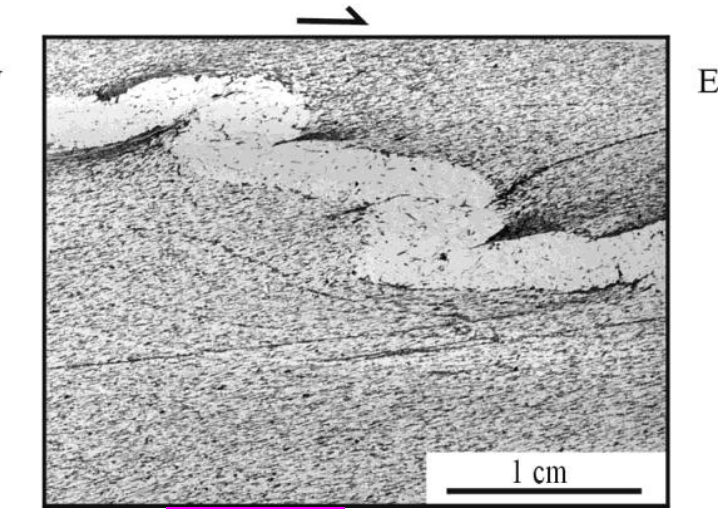

Figure 6a. Horizontal photomicrograph showing a Z-folded Qtz vein parallel to D4 shear planes $6 \mathrm{~b}$ in the semi-aluminous unit (sample 219). What is this? What is horizontal?

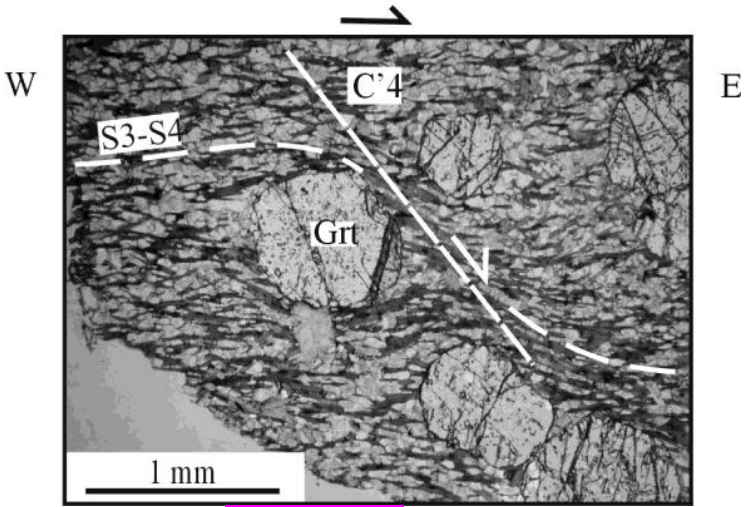

Figure 6b. Horizontal photomicrograph of the semi-aluminous unit (sample 262b). S2-S3 foliation defined by biotite is transposed into dextral $\mathrm{C} 4$ shear bands

$6 \mathrm{c}$

W

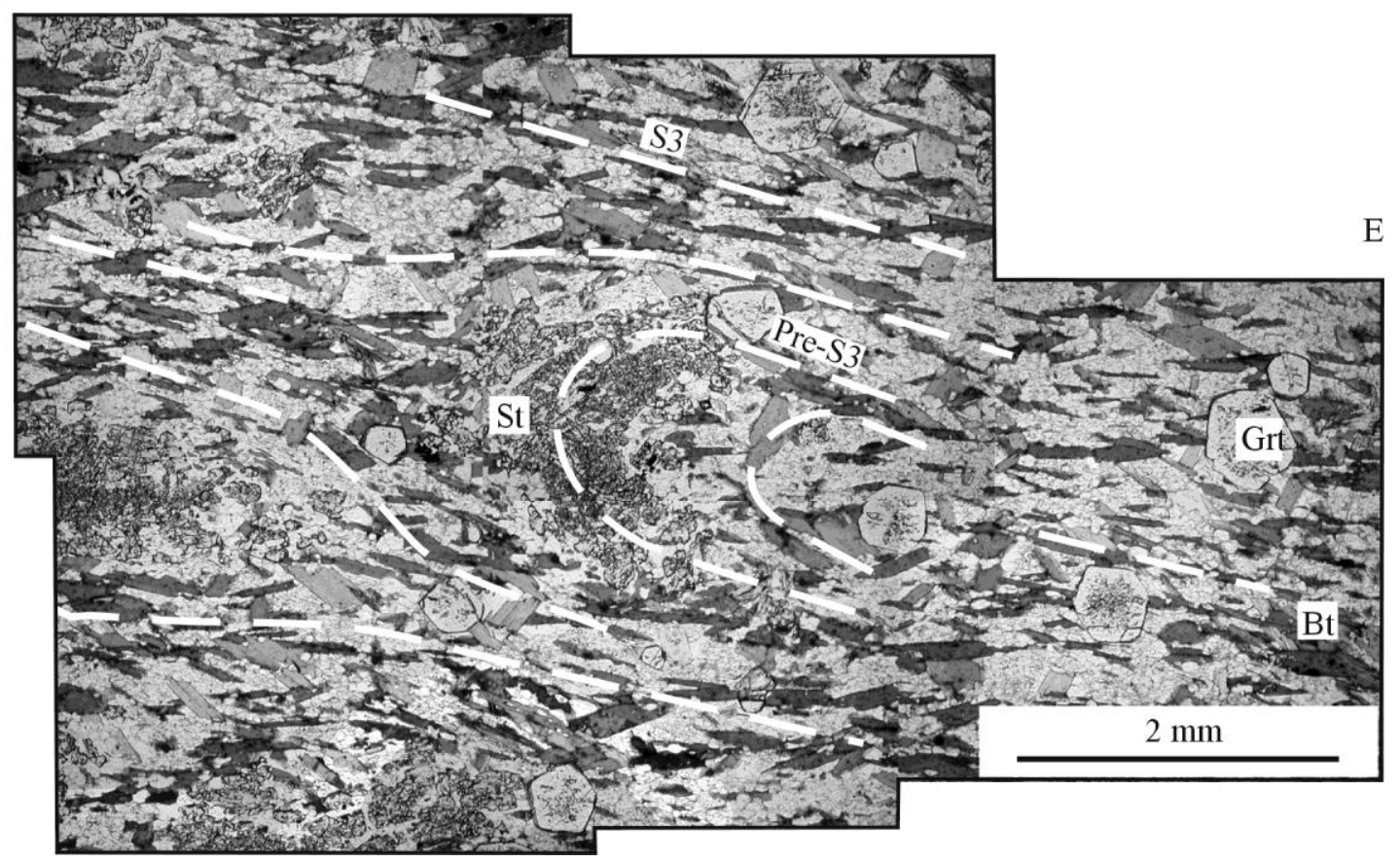


Figure 6c. Photomicrograph of the aluminous unit (sample 251). Staurolite (St) and earlier formed biotite $(\mathrm{Bt})$ are folded by D3 event. A new foliation (S2-S3), which is defined by

$6 \mathrm{~d}$ later biotite, develops in parallel to the axial plane.

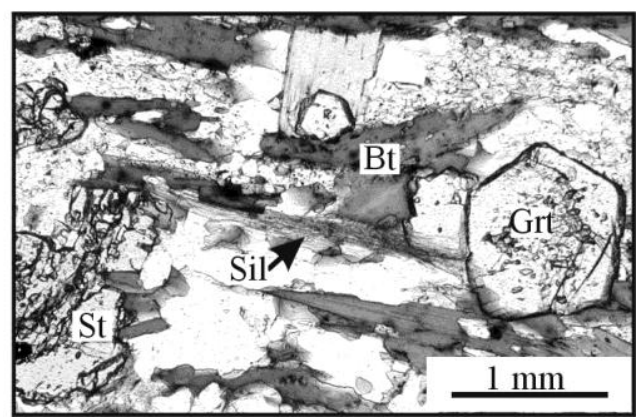

Figure 6d. Photomicrograph of the quartzo-feldsparthic unit (sample 251). Staurolite is replaced by garnet (Grt), biotite $(\mathrm{Bt})$ and sillimanite (Sil).
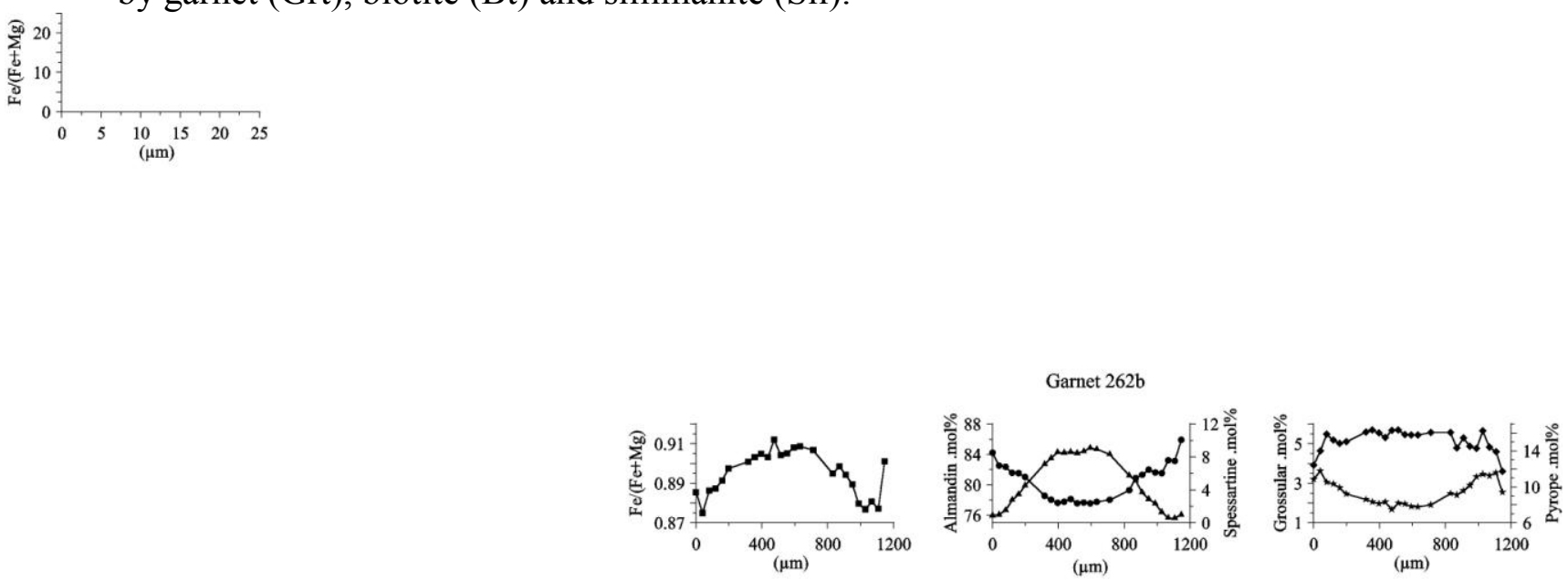

Garnet 244
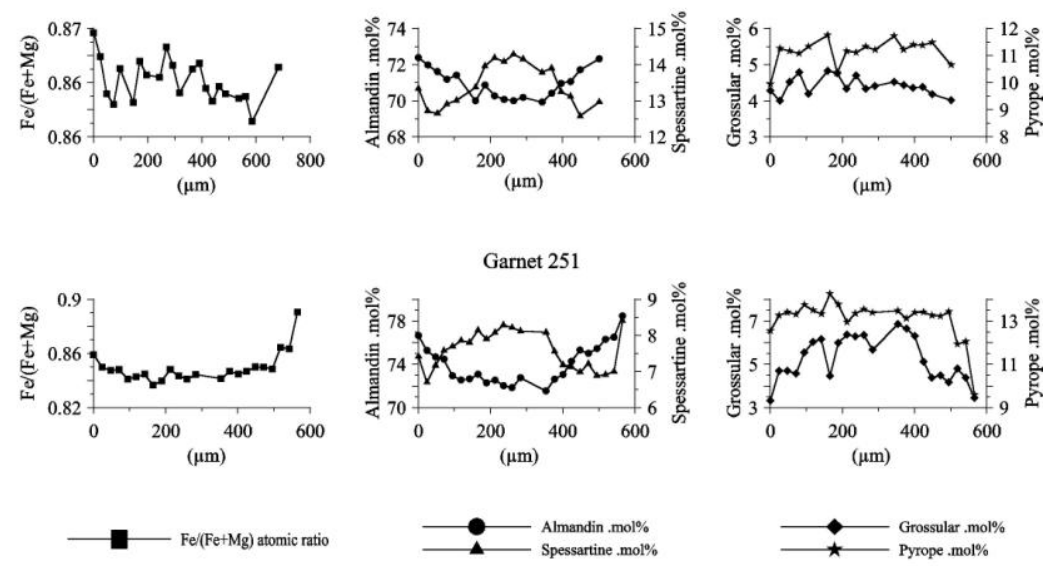

Figure 7. Compositional zoning of selected garnet crystals are presented on rim-core-rim sections. Garnet $262 \mathrm{~b}$ and 244 pertain to the semi-aluminous unit, and garnet 251 to the aluminous unit. $\mathrm{Alm}=100 * \mathrm{Fe} /\left(\mathrm{Fe}^{2+}+\mathrm{Mg}+\mathrm{Ca}+\mathrm{Mn}\right), \operatorname{Prp}=100 * \mathrm{Mg} /\left(\mathrm{Fe}^{2+}+\mathrm{Mg}+\mathrm{Ca}+\right.$ $\mathrm{Mn}), \mathrm{Grs}=100^{*} \mathrm{Ca} /\left(\mathrm{Fe}^{2+}+\mathrm{Mg}+\mathrm{Ca}+\mathrm{Mn}\right), \mathrm{Sps}=100^{*} \mathrm{Mn} /\left(\mathrm{Fe}^{2+}+\mathrm{Mg}+\mathrm{Ca}+\mathrm{Mn}\right)$ (abbreviations are from Kretz, 1983). 

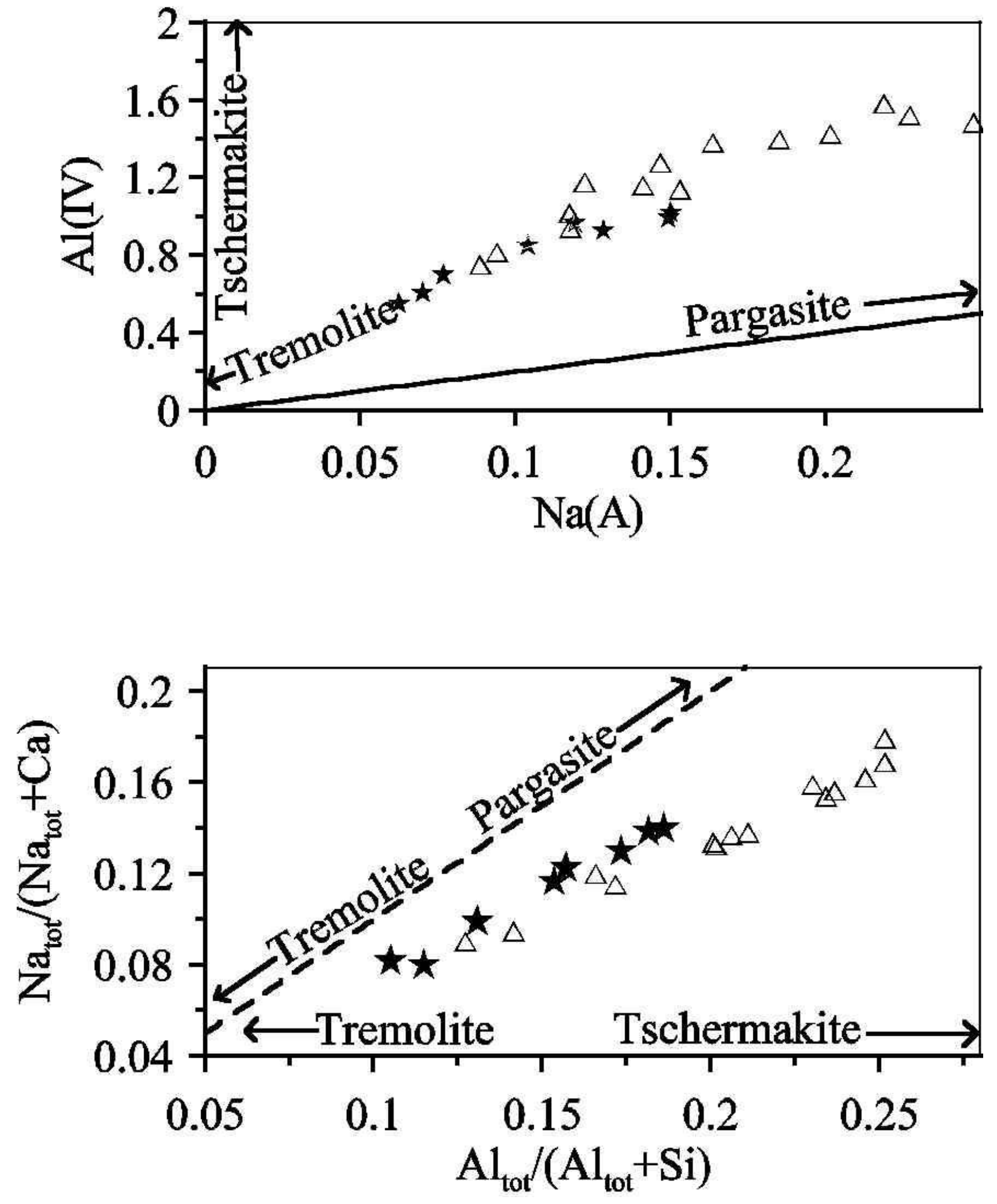
Figure 8. Photomicrograph showing amphibole crystals in samples 252a (left) and 268a (right). Black lines represent the compositional profiles reported in Fig. 9. 
Sample 252a
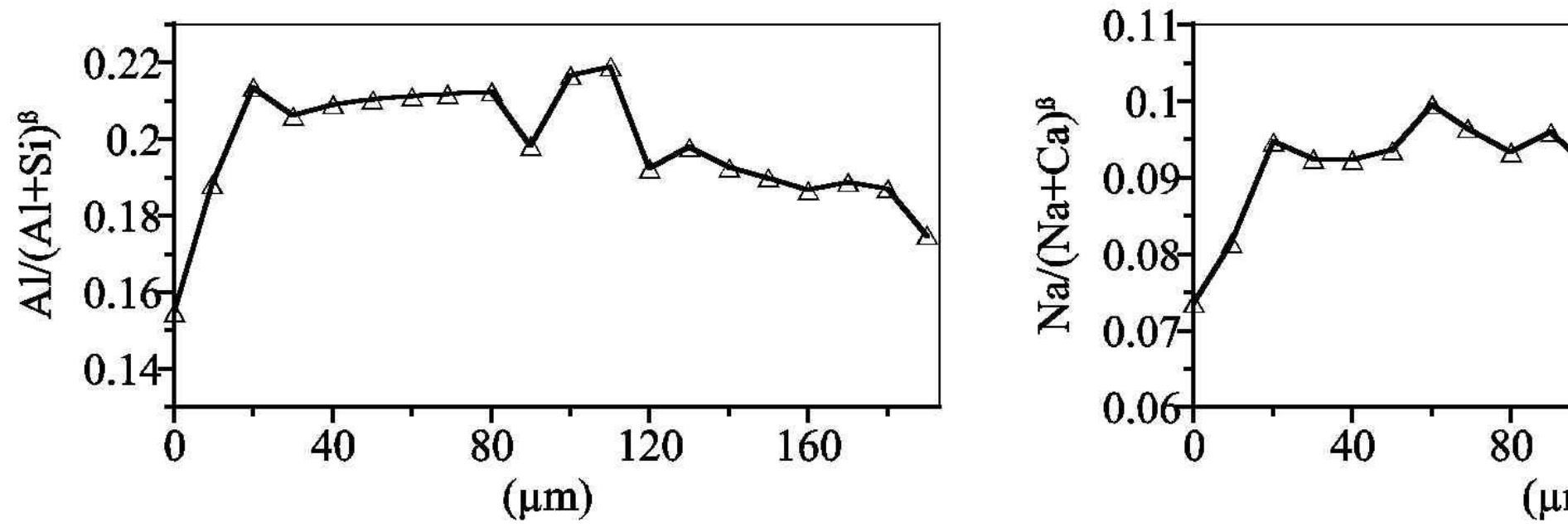

Sample 268a
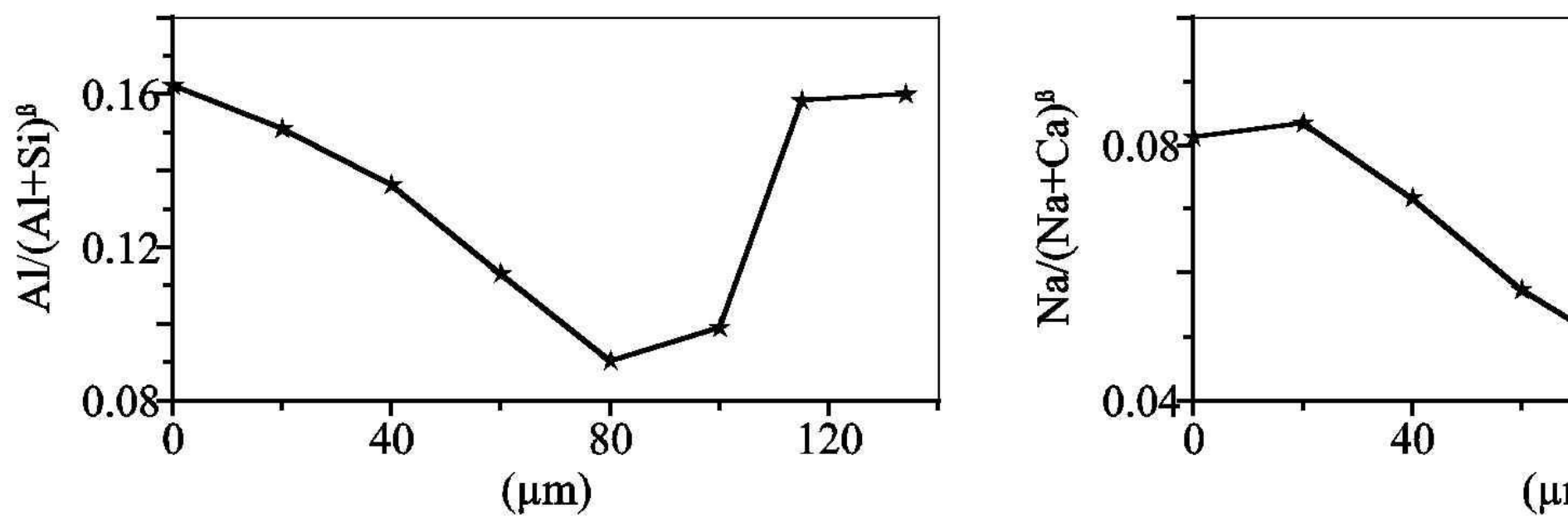

B: atomic ratio 
Figure 9. Compositional profiles of representative amphibole grains in sample 268a (stars) and sample 252a (triangles).

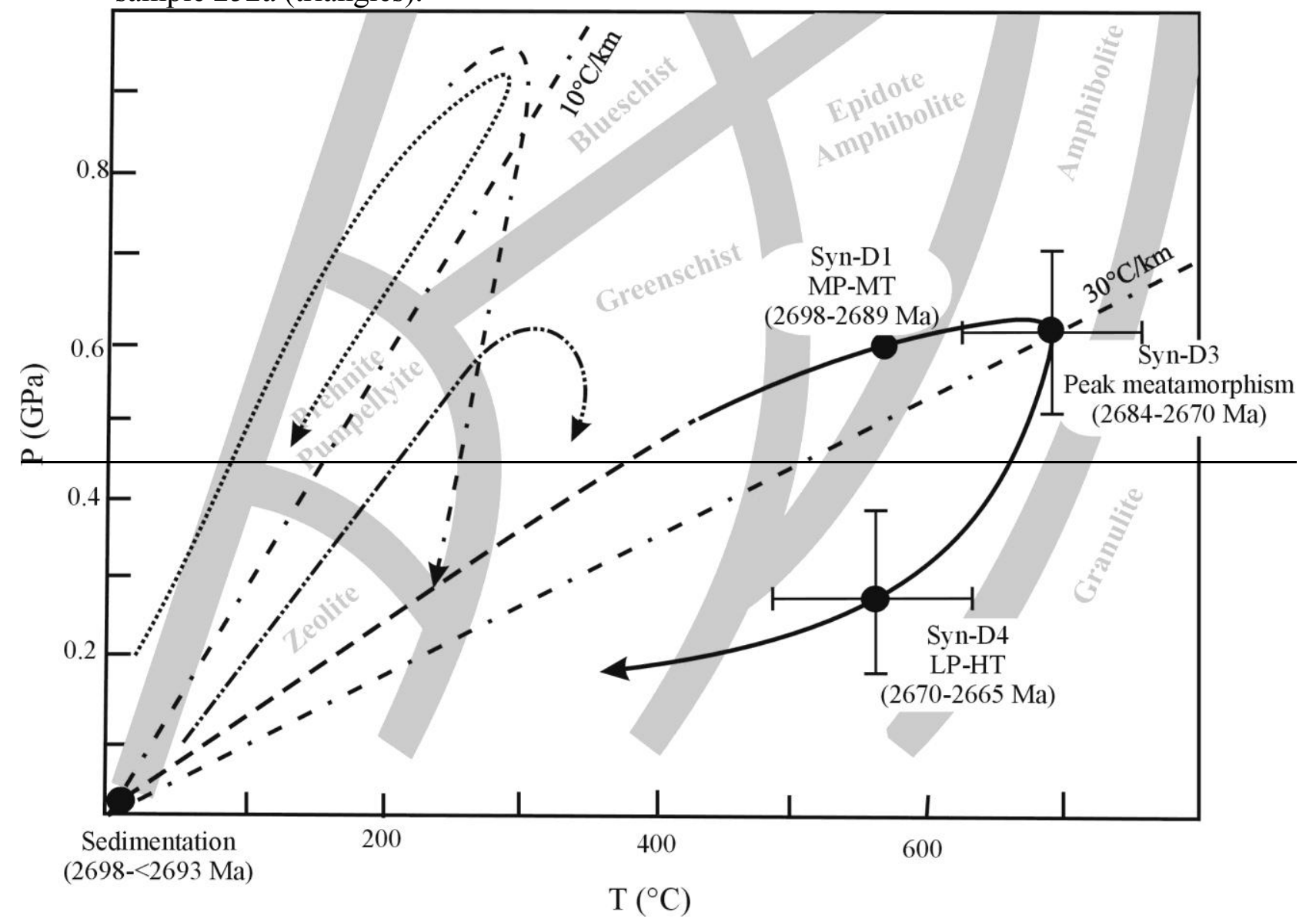

Figure 10. Compositional zoning of amphibole grains in sample 268a (stars) and sample 252a (triangle) from the amphibole-rich unit. Each profile represents an individual grain from rim to rim through the centre of the grain. The grain was selected from four representative grains used for the compositional analysis in each sample. The ratios are atomic.

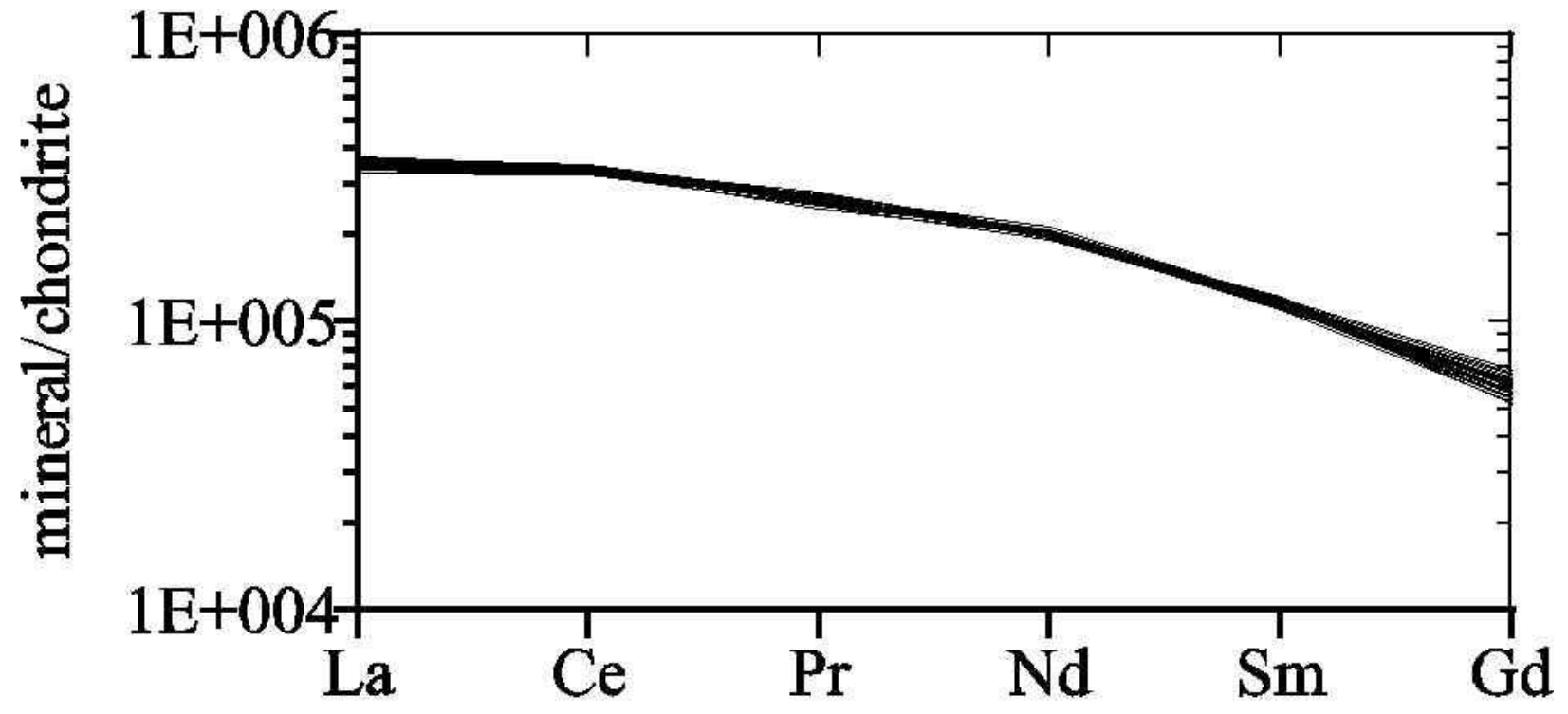


Figure 11. Simplified P-T grid for pelites in the KFMASH system (modified from Spear and Cheney, 1989). "As" refers to Aluminosillicate, other abbreviations of minerals are from Kretz (1983).

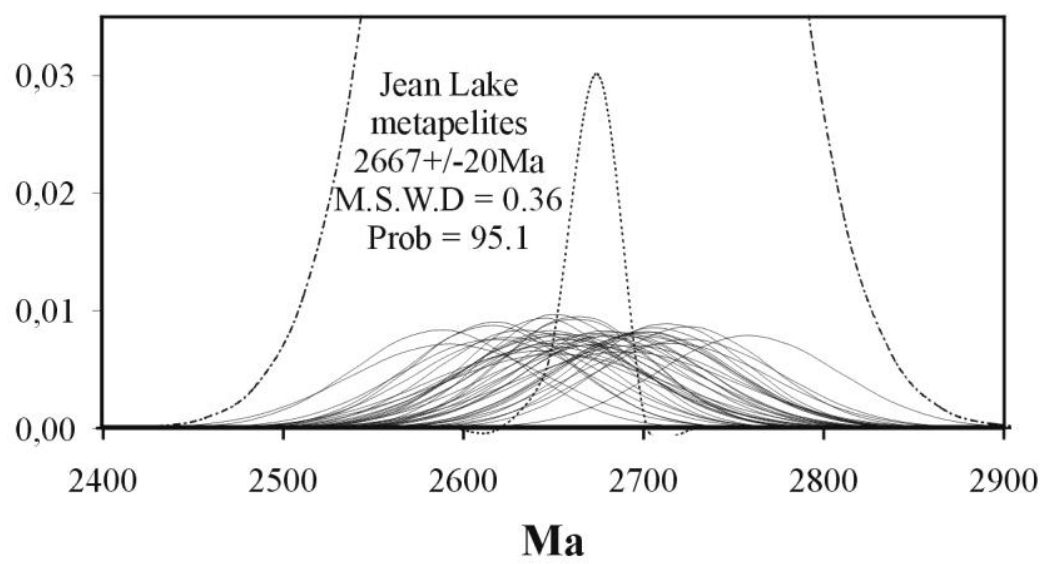

Figure 12. Estimated P-T-t path (solid curve) for the rocks in the Jean Lake area compared to the paths of modern accretionary prisms. Queyras (Schwartz et al., 2000); Sambagawa (Ernst, 1988); and Franciscan (Ernst, 1988). The metamorphic facies are from Spear (1993). Dotdouble-dash lines represent geothermal gradients. 